\author{
Dr. sc. Željka Primorac, docentica
}

Pravni fakultet Sveučilišta u Splitu

\title{
EKOLOŠKE I PRAVNE POSLJEDICE UPORABE BRODSKOG POGONSKOG GORIVA SA SMANJENIM SADRŽAJEM SUMPORA
}

\author{
UDK: 502/504:347. 79 (4) \\ Izvorni znanstveni rad \\ Primljeno: 20.01. 2016.
}

\begin{abstract}
Autorica u radu razmatra ekološke i pravne posljedice uporabe brodskog pogonskog goriva sa smanjenim sadržajem sumpora na smanjenje emisija $\mathrm{SO}_{2} \mathrm{~s}$ brodova. Analizirajući učinkovitost pravnih instrumenata za provedbu zaštite zraka na međunarodnoj i europskoj razini, autorica uspoređuje rješenja Priloga VI. MARPOL-konvencije s rješenjima sekundarnog zakonodavstva Europske unije (direktive 1999/32/EZ, direktive 2005/33/EZ, direktive 2012/33/EZ te Provedbene odluke Komisije (EU) 2015/253) te uspješnost njihova prenošenja u hrvatski pravni sustav. Ukazujući na institucionalni okvir te međunarodne i europske pravne propise, autorica iznosi važeći međunarodni sustav odgovornosti za štetu zbog onečišćenja morskog okoliša izlijevanjem brodskog (pogonskog) goriva s broda (neovisno o sadržaju sumpora u tom gorivu) prema rješenjima Međunarodne konvencije o građanskoj odgovornosti za štete izlijevanjem pogonskog ulja iz 2001. god. Sveobuhvatnom analizom problema praktične primjene brodskog goriva sa smanjenim sadržajem sumpora posebno je razmatran utjecaj usklađivanja s europskim ekološkim zahtjevima na povećanje troškova pomorskog prijevoza. Autorica naglašava neodrživost prometnog sustava zbog dugogodišnje 90-postotne ovisnosti pomorskog prometa o nafti, tj. o neobnovljivom izvoru energije te upućuje na uporabu alternativnih goriva.
\end{abstract}

\section{Ključne riječi: brodsko gorivo, smanjeni sadržaj sumpora}

\section{UVOD}

Statistički podaci pokazuju kako je brodarstvo najmanje ekološki štetno kada se uzme u obzir njegova produktivnost sudjelujući u znatno manjoj mjeri u onečišćenju mora u odnosu na druge ljudske djelatnosti. ${ }^{1}$ Ipak, razvoj brodarske industrije i pomorskog prometa imao je negativne učinke na onečišćenje zraka s brodova. Nafta kao fosilno gorivo, neobnovljiv izvor energije, ekološki je neprihvatljiva iako je dugogodišnje gledano najvažniji energent modernog industrijskog svijeta. Dominanantnost tog izvora energije očituje se i njegovom uporabom kao pogonskog goriva za mnogobrojna prijevozna sredstva, pa tako i za brodove. Izgaranjem fosilnih goriva u brodskim motorima ispuštaju se štetne tvari, a među njima i sumporni dioksid $\left(\mathrm{SO}_{2}\right) \cdot{ }^{2}$ Iako je sumpor u malim količinama

1 Tako prema MITROPOULOS, E. E.: Poruka u povodu svjetskog dana pomorstva (dostupno na http://www.mppi.hr/default.aspx?id=4098, datum posjeta 8. 7. 2015.).

2 Emisija $\mathrm{SO}_{2}$ ovisi izravno o kvaliteti goriva, tj. o sadržaju sumpora u njemu (tako prema MILOŠEVIĆ PUJO', N.; JURJEVIĆ, N.: „Onečišćenje mora iz zraka emisijom ispušnih plinova“, Naše more, br. 5-6, 2004., str. 181. 
prisutan u nafti, više od $90 \%$ sumpora iz goriva emitira se u obliku $\mathrm{SO}_{2} \cdot{ }^{3} \mathrm{Kao}$ takav, $\mathrm{SO}_{2}$ je jedan od glavnih uzroka pojava kiselih kiša, stakleničkih plinova, globalnog zagrijavanja te onečišćenja zraka. Proporcionalno povećanju sumpora u pogonskom brodskom gorivu povećava se i emisija $\mathrm{SO}_{2}{ }_{2}$ što nije za zanemariti jer se oko $90 \%$ svjetske trgovine odvija morskim putem, a pomorski promet je iznimno značajan za svjetska gospodarstva. ${ }^{5}$ Teška dizelska goriva koja su koristili brodovi 2005. god., u prosjeku su sadržavala oko $3 \%$ sumpora pa je najjednostavniji i najjeftiniji način za smanjenje $\mathrm{SO}_{2}$ - smanjenje postotka sumpora u gorivu. ${ }^{6}$ Dizelska goriva s niskim sadržajem sumpora (ULSD - ultra low sulphur diesel) uvedena su da bi se smanjila emisija iz ispušnih plinova i okakšao rad opreme za naknadnu obradu, čija je operabilnost najviše ugrožena sumporom. ${ }^{7}$ Smanjenje sadržaja sumpora u brodskom gorivu ekološki je prihvatljiva mjera sprečavanja onečišćenja zraka s brodova,${ }^{8}$ stoga autorica analizira mjere kojima se na međunarodnoj i regionalnoj razini (EU) nastoji smanjiti sadržaj sumpora u brodskom gorivu kao i postupke kojima se želi utjecati na sprečavanje onečišćenje zraka $\mathrm{s}$ brodova te smanjenje njihove emisije u međunarodnom pomorskom prometu.

\section{MEĐUNARODNI PRAVNI OKVIR SMANJENJA EMISIJE $\mathrm{SO}_{2} \mathrm{~S}$ BRODOVA S POSEBNIM OSVRTOM NA RJEŠENJA PRILOGA VI. MARPOL KONVENCIJE}

Međunarodni pravni okvir smanjenja emisije $\mathrm{SO}_{2} \mathrm{~s}$ brodova počiva na rješenjima brojnih konvencija i protokola kao međunarodnih pomorskopravnih izvora koje normiraju sprečavanje onečišćenja zraka. Među njima neophodno je navesti Konvenciju o prekograničnom onečišćenju zraka na velikim udaljenostima

3 PRELEC, Z.: Inženjerstvo zaštite okoliša, str. 6. (dostupno na www.riteh.uniri.hr/zav-katd-sluz/ zvd_teh-term_energ, 7.7.2015.).

4 Više o emisijama s brodova vidjeti COLLS, J.; TIWARY, A.: Air pollution: Measurement, Modelling and Mitigation, CRC Press, 2009., str. 130.

5 Prema podacima analitičara, svjetska trgovina morem povećana je za oko $135 \%$ između 1985. god. i 2006. god. (tako prema MITROPOULOS, E. E., op. cit. Detaljnije o značaju pomorske plovidbe za svjetsku trgovinu vidi MUKHERJEE, P. K.; BROWNRIGG, M.: Farthing on International Shipping, Springer, 2013., str. 13-18. str. 23

6 LENAC, K.: „Metode smanjivanja emisije štetnih tvari s brodova“, Pomorstvo, Rijeka, br. 1, 2005.

7 POSAVEC, Z.: „Zahtjevi za aditivima nove generacije za dizelska goriva“, Goriva $i$ maziva, Hrvatsko društvo za goriva i maziva, Zagreb, br. 2, 2005., str. 154.

8 Više o prednostima uporabe brodskog goriva sa smanjenim sadržajem sumpora vidjeti KHEE-JIN TAN, A.: Vessel-Source Marine Pollution: The Law and Politics of International Regulation, Cambridge University Press, 2005., str. 157. 
Dr. sc. Željka Primorac: Ekološke i pravne posljedice uporabe brodskog pogonskog goriva sa... Zbornik radova Pravnog fakulteta u Splitu, god. 53, 2/2016., str. 553.-579.

iz 1979. god. ${ }^{9}$ koja regulira mjere za ograničenje i smanjenje onečišćenja zraka ${ }^{10}$ (može se primijeniti i na onečišćenje mora budući da onečišćenje zraka doprinosi i onečišćenju mora) te je kao takva prvi međunarodnopravni obvezujući dokument koji se odnosi na problematiku onečišćenja zraka na široj regionalnoj osnovi. Konvencija je proširena sa 8. Protokola od kojih se sljedeći odnose na smanjenje emisije $\mathrm{SO}_{2}$ u zraku: a) Protokol o smanjenju emisija sumpora ili njihovog prekograničnog strujanja za najmanje $30 \%$ iz 1985. god. ${ }^{11}$ imao je za cilj smanjiti emisiju sumpora kao jednog od najvećih onečišćujućih tvari u zraku; Protokol o daljnjem smanjenju emisije $\mathrm{SO}_{2}$ iz 1994. god. ${ }^{12}$ kojim se propisuje obveza smanjivanja emisija sumpora s ciljem doprinošenja suzbijanju kiselog taloženja sumpora te Protokol o suzbijanju zakiseljavanja, eutrofikacije i prizemnog ozona iz 1999. god. ${ }^{13}$ kojim se propisuju gornje granice emisija za sumpor u tisućama tona $\mathrm{SO}_{2}$ godišnje. ${ }^{14}$

Međunarodno obilježje pomorskog prijevoza dodatno naglašava i međunarodni problem uporabe pogonskog brodskog goriva lošije kvalitete zbog visokog sadržaja sumpora u njemu. Radi se o tome da je takvo gorivo 2700 puta prljavije od goriva koje se koristi u cestovnom prijevozu ${ }^{15}$ (16 najvećih svjetskih brodova

9 Convention on Long-Range Transboundary Air Pollution, dalje: LRTAP-konvencija stupila je na snagu 1983. god. Prema Odluci o objavljivanju mnogostranih međunarodnih ugovora kojih je Republika Hrvatska stranka na temelju notifikacija o sukcesiji, Republika Hrvatska je stranka navedene konvencije od 8. listopada 1991. god. (NN, MU, br. 12/1993). Više o LRTAP vidjeti REDGWELL, C.: „The Application of International Law“, u: International Law, OUP Oxford, 2010., str. 702.

10 Onečišćenje zraka označava unošenje u atmosferu od strane čovjeka, posredno ili neposredno, tvari ili energije sa štetnim djelovanjem, koje po svojoj prirodi mogu dovesti u opasnost zdravlje čovjeka, nanijeti štetu biološkim resursima i ekosistemima te materijalnim dobrima i ugroziti ili narušiti estetske vrijednosti i druge zakonite namjene čovjekove okoline (čl. 1. LRTAP-konvencije).

11 Protocol on the Reduction of Sulphur Emissions or their Transboundary Fluxes by at least 30 per cent, 1985., stupio na snagu 1988. god., RH nije ratificirala ovaj Protokol (tekst Protokola dostupan na www.unece.org/fileadmin/DAM/env/lrtap/full text/1985.Sulphur.e.pdf, 16. 7. 2015.). Detaljnije vidjeti GILlESPIE, A.: Climate Change, Ozone Depletion and Air Pollution, BRILL, 2006., str. 194.

12 Protocol to the 1979 Convention on Long-Range Transboundary Air Pollution on further reduction of sulphur emissions, 1994., stupio na snagu 1998. god., RH je stranka Protokola od 27. travnja 1999. god. (vidjeti Zakon o potvrđivanju Konvencije o dalekosežnom prekograničnom onečišćenju zraka iz 1979. god. NN, MU, br. 17/1998).

13 Protocol to the 1979 Convention on Long-Range Transboundary Air Pollution to abate Acidification, Eutrophication and Ground - Level Ozone, 1999., RH ga je potpisala 30. studenoga 1999. god., na snazi je od 5. siječnja 2009. god. (vidjeti Zakon o potvrđivanju Protokola o suzbijanju zakiseljavanja, eutrofikacije i prizemnog ozona uz Konvenciju o dalekosežnom prekograničnom onečišćenju zraka, NN, MU, br.4/2008).

14 Prema Dodatku II. predmetnog Protokola, RH je 1980. god. imala razinu emisija za sumpor 150.000 t/godišnje, a 1990. god. 180.000 t/godišnje. Gornje granice emisija za sumpor u 2010. god. bile su 70.000 t/godišnje. Postotak smanjenja emisija za 2010. god. je 61 \% manji u odnosu na 1990. god.

15 Vidi tablični prikaz usporedbe emisija $\mathrm{SO}_{2}$ iz motornih vozila i s brodova (Truck versus ship emissions, u: Air Pollution from ships, 2004., str. 5. (dostupno na http://www.transportenvironment.org/ sites/te/files/media/2004-11_joint_ngo_air_pollution_from_ships.pdf, 20. 7. 2015.). Detaljnije u odnosu na emisiju $\mathrm{SO}_{\mathrm{x}}$ ovisno o vrsti pogonskih goriva prijevoznih sredstava i najvećem sadržaju sumpora u brodskom pogonskom gorivu vidjeti Stationary sources vs ships, u: Air Pollution from ships, 2004. str. 6. (dostupno na http://www.transportenvironment.org/sites/te/files/media/2004-11_joint_ngo_air_ pollution_from_ships.pdf, 20.7. 2015.). 
Dr. sc. Željka Primorac: Ekološke i pravne posljedice uporabe brodskog pogonskog goriva sa... Zbornik radova Pravnog fakulteta u Splitu, god. 53, 2/2016., str. 553.-579.

može prouzročiti onečišćenje zraka sumporom kao svi svjetski automobili)16 pa slobodno možemo zaključiti kako je brodski motor jedan od najvećih onečišćivača mora i zraka ${ }^{17}$ - emisijama ispušnih plinova. S obzirom na nužnost sprečavanja i ograničavanja onečišćenja zraka ispuštanjem $\mathrm{SO}_{2} \mathrm{~s}$ brodova te neophodnost nadzora sve većeg onečišćenja zraka emisijama $\mathrm{SO}_{2} \mathrm{~s}$ brodova, ${ }^{18}$ nužno je izraditi međunarodni pravni okvir, posebice što isključivo reguliranje zaštite mora od onečišćenja iz zraka ne postoji ni unutar međunarodnih ni regionalnih ugovora. ${ }^{19}$

Prva višestrana konvencija sklopljena s ciljem zaštite morskog okoliša i najznačajnija konvencija kada je riječ o sprečavanju onečišćenja mora s brodova već 40 godina jest Međunarodna konvencija o sprečavanju onečišćenja mora s brodova iz 1973. god. ${ }^{20}$ Osnovna svrha ove konvencije jest spriječiti onečišćenje mora s brodova neovisno o tomu je li ono posljedica izvanrednih događaja (pomorskih nesreća) ili redovitih brodskih operacija. Kao najtemeljitiji i najpotpuniji propis, MARPOL konvencija ima za cilj eliminirati onečišćenje morskog okoliša svim tvarima koje potječu s brodova. MARPOL konvencija ima 6 priloga koji se odnose na različite vrste onečišćenja s brodova. Prilog VI. MARPOL konvencije ${ }^{21}$ uređuje sprečavanje onečišćenja zraka emisijama plinova s brodova sadržavajući pravila o tehničkim zahtjevima u odnosu na pogonsko brodsko gorivo i njegov sadržaj sumpora. Pravilom 14. Unutar spomenutog Priloga prvi je put propisano ograničenje količine sumpora u svakom gorivu koje se na brodu koristi (plinsko ulje - dizel, bezolovni motorni benzin), a riječ je o pogonskom gorivu broda (većeg od $400 \mathrm{BT})^{22}$ s unutarnjim izgaranjem. Prema

16 LEWIS, G.: How 16 cars create as much pollution as all the cars in the world, 2009., str. 1 (dostupno na http://www.dailymail.co.uk/sciencetech/article-1229857/How-16-shi..., 13. 7. 2015.).

17 Više vidjeti DAVENPORT, J.; DAVENPORT, J. L.: The Ecology of Transportation: Managing Mobility for the Environment, Springer, Nizozemska, 2006., str. 362-363.

18 Više o nužnosti stalnog nadzora sadržaja sumpora u gorivu vidjeti kod POSAVEC, Z.: ,Tko se boji sumpora još?“", Goriva i maziva, Hrvatsko društvo za goriva i maziva, Zagreb, br. 4, 2005., str. 289.

19 MILOŠEVIĆ PUJO, N.; JURJEVIĆ, N., op. cit., str. 183.

20 International Convention for the Prevention of Pollution from Ships, dalje: MARPOL konvencija. Donesena je 17. veljače 1973. god. u Londonu. U RH je ova konvencija na snazi od 8. listopada 1991. god. (Odluka o objavljivanju mnogostranih međunarodnih ugovora kojih je Republika Hrvatska stranka na temelju notifikacije o sukcesiji, NN, MU, br. 1/1992.). Detaljnije o sprečavanju onečišćenja mora s brodova prema rješenjima MARPOL-konvencije vidjeti kod LUTTENBERGER, A.: Pomorsko upravno pravo, Sveučilište u Rijeci, Pomorski fakultet, Rijeka, 2008., str. 23-25; SERŠIĆ, M.: Međunarodno-pravna zaštita morskog okoliša, Pravni fakultet Sveučilišta u Zagrebu, Zagreb, 2003., str. 83-87; STANKOVIĆ, P.: Pomorske havarije, Śkolska knjiga, Zagreb, 1995., str. 119-121.

21 Prilog VI. MARPOL konvencije prihvaćen je Protokolom od 26. rujna 1997. god. (Protocol of 1997 to amend the International Convention for the Prevention of Pollution from Ships of 2 November 1973), a na snazi je od 19. svibnja 2005. god. (ovaj Protokol je stupio na snagu 12 mjeseci od dana kada ga je ratificiralo 15 država čija je zajednička trgovačka flota činila minimalno 50 \% bruto tonaže svjetske trgovačke flote. Do danas 83 države pristupilo je Protokolu iz 1997. god. odnosno 95,3 \% svjetske tonaže - vidi www.imo.org). Protokol iz 1997. god. kojim se mijenja MARPOL konvencija za RH je na snazi od 4. kolovoza 2005. god. (vidi Uredba o objavi Protokola iz 1997. god. kojim se mijenja i dopunjuje Međunarodna konvencija o sprečavanju onečišćenja mora s brodova iz 1973., NN, MU, br. 4/05).

22 Prilog VI. MARPOL konvencije primjenjuje se na brodove veće od 400 BT (detaljnije vidjeti Prevention of air pollution from ships, UK P\&I Club, Legal Briefing, Stricker air pollution regulations on the horizon, lipanj 2014., str. 4. (dostupno na http://www.ukpandi.com/fileadmin/uploads/uk-pi/Latest Publications/LEGAL_BRIEFINGS/UKLegal_Emissions_web.pdf, 20. 7. 2015.). 
Dr. sc. Željka Primorac: Ekološke i pravne posljedice uporabe brodskog pogonskog goriva sa... Zbornik radova Pravnog fakulteta u Splitu, god. 53, 2/2016., str. 553.-579.

njegovim rješenjima, globalno ograničenje glede sadržaja sumpora u brodskom gorivu iznosilo je $4,5 \%{ }^{23} \mathrm{~m} / \mathrm{m}$ za područja u kojima nije bila ograničena emisija $\mathrm{SO}_{2} \mathrm{u}$ ispušnim plinovima te je u odnosu na Baltičko more, ${ }^{24} \mathrm{kao}$ posebno područje nadzora nad emisijama sumpora (Sulphur Emission Control Areas - SECA), ${ }^{25}$ sadržaj sumpora bio ograničen na $1,5 \% \mathrm{~m} / \mathrm{m}$. Nakon stupanja na snagu Priloga VI. MARPOL konvencije (19. svibnja 2005. god.) kao SECA su određena i područja Sjevernog mora, uključujući i Engleski kanal. ${ }^{26}$ No, kako je od donošenja Priloga VI. MARPOL konvencije do stupanja na snagu istog prošlo 8 godina, već nakon njegova stupanja na snagu krenulo se izradi revizije Priloga. ${ }^{27}$ Revizija Priloga VI. prihvaćena je rezolucijom MEPC. 176(58) u listopadu 2008. god. (stupilo na snagu 1. srpnja 2010. god.), uspostavljajući kontrolu kvalitete goriva na globalnoj razini te posebne kontrole za brodove koji plove u posebnim područjima. Prema Pravilu 14. revidiranog Priloga VI. MARPOL konvencije progresivno je ograničen sadržaj sumpora u brodskom gorivu. Naime, sadržaj sumpora u brodskom gorivu nije smio prelaziti: 4,50 \% do 1. siječnja 2012. god, 3,50 \% nakon 1. siječnja 2012. god. odnosno ne smije prelaziti $0,50 \%$ nakon 1. siječnja 2020. god. Revizijom Priloga VI. MARPOL konvencije iz 2008. god. također se uvode strože granične vrijednosti sumpora za brodska goriva u SECA područjima (od 2010. god. SECA područje je prošireno na zonu Sjeverne Amerike koja obuhvaća obalni pojas sjevernoameričkog kontinenta - SAD i Kanadu u širini od 200 Nm od obale ${ }^{28}$

23 Riječ je o iznosu koji je čak 4500 puta viši u odnosu na dozvoljeni sadržaj sumpora u gorivu koja uporabljuju cestovna motorna vozila u EU (više vidjeti LEWIS, G., op. cit., str. 2. U cestovnom prometu, na tržištu V. Britanije već je krajem 90-ih godina prošlog stoljeća uvedeno dizelsko gorivo razine sadržaja sumpora od 0,005 \%, a u Njemačkoj su pripremili prelazak na gorivo sa samo 0,001\% sumpora 2003. god. (tako prema LEGIŠA, I.: „Što nam donosi smanjenje sadržaja sumpora u gorivima“, Goriva i maziva, Hrvatsko društvo za goriva i maziva, Zagreb, br. 4, 2002., str. 1). Dopušteni sadržaj sumpora za goriva motornih vozila u EU pao je sa 350 ppm (0,035 \%) u 1980. god. na nula (0 \%) u 2009. god. - više vidjeti kod GILLESPIE, A., op. cit., str. 203.

24 Baltičko more je prihvaćeno kao područje u kojem se nadzire ispuštanje SO 26. rujna 1997. god., primjena od 19. svibnja 2005. god. (od stupanja na snagu Protokola iz 1997. god. kojim se unosi Prilog VI. MARPOL konvencije). Detaljnije vidjeti Special Areas under MARPOL (dostupno na http://www. imo.org/en/OurWork/Environment/SpecialAreasUnde..., 14. 7. 2015.). Baltičko more kao SECA vrlo je značajna pomorska ruta gdje svakodnevno plovi preko 2000 brodova. Više o onečišćenju emisijama SOx na području Baltičkog mora vidjeti SIMPSON, D.; JERZY BARTNICKI, J.; JALKANEN, J. K.; HANSSON, H. C.; HERTEL, O.; LANGER, J.; PRYOR, S. C.: „Environmental Impacts Atmospheric Chemistry“, u: Second Assessment of Climate Change for the Baltic Sea Basin, Springer, 2015., str. 271272 .

25 Područje u kojem se nadzire ispuštanje Sox - SECA jest područje za koje se zahtijeva primjena posebnih obvezatnih mjera za ispuštanje $\mathrm{SOx} s$ brodova radi sprečavanja, smanjivanja i kontrole onečišćenja zraka s SOx. U tim područjima mora se koristiti gorivo niskog sadržaja sumpora (low sulphur fuel). Više o SECA vidjeti KACHEL, M. J.: Particularly Sensitive Sea Areas: The IMO 's Role in Protecting Vulnerable Marine Areas, Springer Science \& Business Media, 2008., str. 102-103.

26 Sjeverno more je prihvaćeno kao područje u kojem se nadzire ispuštanje SOx 22. lipnja 2005. god., primjena od 22. studenoga 2007. god. - detaljnije vidjeti FRANK, V.: The European Community and MarineEnvironmental Protection in the International Law of the Sea, BRILL, 2007., str. 368.

27 Više vidjeti SAIFUL, K. MD.: Prevention of Pollution of the Marine Environment from Vessels: The Potential and Limits of the International Maritime Organisation, Springer, 2014., str. 51.

28 Navedeno područje prihvaćeno je kao SECA 26. svibnja 2010. god., primjena od 1. kolovoza 2011. god. (detaljnije vidjeti Special Areas under MARPOL, op. cit., bilj. 24.). Detaljnije vidjeti WILCOX, E. R.: Digest of United States Practicein International Law, Oxford University Press, 2012., str. 546-547. 
Dr. sc. Željka Primorac: Ekološke i pravne posljedice uporabe brodskog pogonskog goriva sa... Zbornik radova Pravnog fakulteta u Splitu, god. 53, 2/2016., str. 553.-579.

te Karipsko more ${ }^{29}$ ) određujući kako sadržaj sumpora u brodskom gorivu u tim područjima nije smio prelaziti $1,50 \%$ prije 1 . srpnja 2010. god, 1,00 \% nakon 1 . srpnja 2010. god. odnosno 0,10\% nakon 1. siječnja 2015. god.

Značajno je ukazati kako je plovidba Baltičkim morem, Sjevernim morem i Sjevernim Atlantikom u 90-tim godinama prošlog stoljeća rezultirala stvaranjem 2 milijuna tona $\mathrm{SO}_{2}, 2000$. god. taj se iznos povećao na 2,6 milijuna tona dok se u odnosu na 2010. god. očekivalo da će ukupan iznos emisija $\mathrm{SO}_{2} \mathrm{~s}$ brodova iznositi oko 3,3 milijuna tona. ${ }^{30}$ Uporaba brodskog goriva $\mathrm{u}$ jednoj godini proizvede zapanjujućih 16,5 milijuna tona $\mathrm{SO}_{2} \cdot{ }^{31}$ Također je važno uočiti kako od 1. siječnja 2015. god. pravno obvezujuće norme propisuju kako svaki brod mora upotrebljavati gorivo čiji je sadržaj sumpora visoke kvalitete čime će se utjecati pozitivno na osiguravanje bolje kvalitete zraka posebice u odnosu na činjenice da predmetna rješenja obuhvaćaju čak 95,23\% svjetske tonaže te da se većina svjetske trgovine obavlja morima kojima plovi oko 90.000 prekooceanskih trgovačkih brodova od kojih $90 \%$ koristi dizel kao brodsko gorivo. ${ }^{32}$ U 2004. god. skoro $90 \%$ svjetskog brodskog goriva činilo je pogonsko gorivo sa 2-postotnim sadržajem sumpora, dok se oko $44 \%$ sveg dostavljenog pogonskog goriva odnosilo na pogonsko gorivo sa 3-postotnim sadržajem sumpora. ${ }^{33} \mathrm{U} 2006$. god. brodovi su potrošili 369 milijuna tona pogonskog goriva od čega je $77 \%$ teško gorivo. ${ }^{34} \mathrm{U}$ 2014. god. međunarodna pomorska plovidba je prouzročila emisije $\mathrm{SO}_{2}$ koje su predstavljale oko $12 \%$ ukupnih globalnih emisija $\mathrm{SO}_{2}{ }^{35} \mathrm{Za}$ očekivati je da će temeljem zahtjeva iz Priloga VI. MARPOL konvencije navedene emisije opadati iako se i nakon stupanja na snagu predmetnog Priloga u odnosu na SECA područja: Baltičko more, Sjeverno more i Engleski kanal predviđao rast emisije $\mathrm{SO}_{2}$ za više od $42 \%$ do 2020 . god. ${ }^{36}$

29 Karipsko more je prihvaćeno kao posebno područje nadzora emisije SOx 26. srpnja 2011. god., a primjenjuje se od 1. siječnja 2014. god. (dostupno na http://www.imo.org/en/OurWork/Environment/ SpecialAreasUnde..., 14. 7. 2015.). Više o određivanju područja oko Puerto Rica i Američkih Djevičanskih otoka kao SECA područja od siječnja 2014. vidjeti Designation of Emission Control Area to Reduce Emissions from Ships in the U.S. Caribbean, Office of Transportation and Air Quality EPA-420-F-11-024, srpanj 2011., str. 1.

30 Tako prema ABEL, D. A.; McCONNELL, R. L: Environmental Oceanography: Topics and Analysis, Jones \& Bartlett Publishers, 2009., str. 154.

31 ZANNE, M.; TWRDY, E.: „Air Pollution from Maritime Transport - the Problem of Today, the Challenge of Tommorow“, Pomorstvo, br. 1., 2011., str. 104.

32 Dizelski motori, iako pouzdani, efikasni, laki za održavanje, moraju udovoljiti i zahtjevima za što nižom emisijom štetnih plinova (tako prema MILOŠEVIĆ PUJO, N.; JURJEVIĆ, N., op. cit., str. 183).

33 Tako prema Marpol Annex VI sets sulphur test (dostupno na http://dnv.no/din_bransje/maritime/ publikasjoner/publications..., 20. 7. 2015.).

34 ZANNE, M.; TWRDY, E., op. cit., str. 104.

35 Third IMO GHG Study 2014, str. 2. (dostupno na http://www.imo.org/Our/Work/Environment/ PollutionPrevention/Air, 15. 5. 2015.).

36 Tako prema „Increasing emissions“, u: Air Pollution from ships, 2004., str. 3 (dostupno na http://www.transportenvironment.org/sites/te/files/media/2004-11_joint_ ngo_air_pollution_from_ships.pdf, 20.7.2015.). 


\section{EUROPSKI PRAVNI OKVIR SMANJENJA EMISIJE $\mathrm{SO}_{\mathrm{x}} \mathrm{S}$ BRODOVA S POSEBNIM OSVRTOM NA SEKUNDARNO ZAKONODAVSTVO EUROPSKE UNIJE TE USPJEŠNOST IMPLEMENTACIJE U REPUBLICI HRVATSKOJ}

$\mathrm{Na}$ europskoj razini svakodnevno je sve više očita energetska učinkovitost prometa, ali nafta i naftni derivati još uvijek se koriste za $96 \%$ prometnih energetskih potreba u EU. ${ }^{37} \mathrm{U}$ EU promet sudjeluje sa $10 \%$ EU BDP-a ${ }^{38}$ a pomorska plovidba je najvažniji izvor onečišćenja zraka u EU. Budući da izgaranjem tekućih goriva dolazi do emisija $\mathrm{SO}_{2}$, smanjenje predmetnih emisija prioritet je EU. Po uzoru na prethodno analizirana rješenja na međunarodnoj razini, smanjenje emisija $\mathrm{SO}_{2}$ na europskoj razini također se postiže uvođenjem granica za sadržaj sumpora u brodskim pogonskim gorivima.

\subsection{Direktiva Vijeća 1999/32/EZ od 26. travnja 1999. god. o smanjenju sadržaja sumpora u određenim tekućim gorivima}

Prvi korak u smanjenju emisija $\mathrm{SO}_{2} \mathrm{~s}$ brodova na europskoj razini predstavlja donošenje Direktive Vijeća 1999/32/EZ od 26. travnja 1999. god. o smanjenju sadržaja sumpora u određenim tekućim gorivima. ${ }^{39}$ Direktiva 1999/32/EZ imala je za cilj smanjiti emisije sumporovog dioksida koje nastaju spaljivanjem određenih vrsta tekućih goriva i time smanjiti štetne posljedice takvih emisija za čovjeka i okoliš (čl. 1.) propisujući najviši dopušteni sadržaj sumpora u brodskom gorivu ${ }^{40}$ koje se koristilo u EU. ${ }^{41}$ Temeljem odredbe čl. 4., st. 1. države članice EU morale su poduzeti sve potrebne mjere kako bi osigurale da se goriva za plovila ne koriste na njihovom državnom području i to: od srpnja 2000. ako sadrže više od $0,20 \%$ sumpora po masi; te od 1 . siječnja 2008. ako sadrže više od $0,10 \%$ sumpora po masi. ${ }^{42}$ Iznimka je bila propisana u odnosu na Španjolsku (za Kanarske otoke), Francusku (za francuske prekomorske zemlje), Grčku (za svoje ukupno državno područje) i Portugal (za arhipelage Madeiru i Azore). U odnosu na navedena

37 Tako prema Bijeloj knjizi, Plan za jedinstveni europski prometni prostor-Put prema konkurentnom prometnom sustavu unutar kojeg se učinkovito gospodari resursima, Bruxelles, COM(2011) 144 final, 28. 3. 2011., str. 4.

38 Tako prema JUGOVIĆ, A.; ŽANIĆ MIKULIČIĆ, J.; MAGLIĆ, L.: „Impact of external costs on the implementation of Motorways of the Sea system“, Pomorstvo, Pomorski fakultet u Rijeci, br. 1, 2014. str. 17.

39 Direktiva Vijeća 1999/32/EZ od 26. travnja 1999. god. o smanjenju sadržaja sumpora u određenim tekućim gorivima (Council Directive 1999/32/EC of 26 April 1999 relating to a reduction in the sulphur content of certain liquid fuels), Official Journal of the European Communities, L121, 26. 04. 1999., str. 13-18, dalje: Direktiva 1999/32/EZ).

40 Brodska goriva su goriva za pomorsku uporabu (čl. 2., st. 1., t. 3. Direktive 1999/32/EZ).

41 Detaljnije vidjeti „EU encourages stringent measures“, UK P\&I Club, Legal Briefing, Stricker air pollution regulations on the horizon, lipanj 2014., str. 7. (dostupno na http://www.ukpandi.com/fileadmin/ uploads/uk-pi/Latest_Publications/LEGAL_BRIEFINGS/UKLegal_Emissions_web.pdf, 20. 7. 2015.).

42 Više vidjeti SONG, D. W.; PANAYIDES, P. M.: Maritime Logistics: Contemporary Issues, Emerald Group Publishers, 2012., str. 271. 
Dr. sc. Željka Primorac: Ekološke i pravne posljedice uporabe brodskog pogonskog goriva sa... Zbornik radova Pravnog fakulteta u Splitu, god. 53, 2/2016., str. 553.-579.

područja, dopušteno je bilo odobriti uporabu brodskih goriva sa sadržajem sumpora koji prelazi granične količine navedene u čl. 4., stavku 1. predmetne direktive.

Direktiva 1999/32/EZ značajna je za postizanje održivosti pomorskog prometa budući da navedenim rješenjima glede smanjenja sadržaja sumpora u brodskim gorivima doprinosi smanjenju emisija sumporovog dioksida s brodova. Ipak, neodgovarajući režim praćenja njezine provedbe te nepostojanje sustava učinkovitih, proporcionalnih i odvraćajućih sankcija za neusklađenost s njom smatrane su vrlo značajnim kritikama koje je trebalo uvažiti i unaprijediti tadašnja rješenja.

\section{2. Direktiva 2005/33/EZ Europskog Parlamenta i Vijeća od 6. srpnja 2005. god. o izmjeni Direktive 1999/32/EZ}

Direktiva 2005/33/EZ Europskog Parlamenta i Vijeća od 6. srpnja 2005. god. o izmjeni Direktive 1999/32/EZ ${ }^{43}$ donesena je u skladu s rješenjima direktive 1999/32/EZ vezano za prijedlog smanjenja graničnih vrijednosti sumpora za brodska goriva u kontrolnim područjima emisije $\mathrm{SO}_{\mathrm{x}}$. Također su rješenja predmetne direktive usklađena sa zahtjevima za pogonskim gorivom smanjenog sadržaja sumpora u EU prema rješenjima Priloga VI. MARPOL konvencije. Naime, istraživanja su pokazala da su do 2010. god. emisije $\mathrm{SO}_{2}$ s brodova odgovarale 75-postotnim emisijama iz svih kopnenih izvora. ${ }^{44}$ Direktiva 2005/33/ EZ mijenja Direktivu 1999/32/EZ utvrđujući najniži dopušteni udio sumpora kod brodskog pogonskog goriva. ${ }^{45}$ Predmetna direktiva je unutar čl. 4.a) propisala najveći sadržaj sumpora u gorivima za plovila koja se uporabljuju na područjima nadzora nad emisijama $\mathrm{SO}_{2}$ i koja rabe putnički brodovi na linijskoj plovidbi prema lukama u EU ili iz njih. Prema navedenim rješenjima, države članice EU bile su dužne poduzeti sve potrebne radnje kako bi osigurale da se brodska goriva čiji sadržaj sumpora prelazi 1,5\% masenog udjela ne uporabljuju na područjima njihovih teritorijalnih mora, isključivih gospodarskih zona i zona suzbijanja onečišćenja koje pripadaju područjima nadzora nad emisijama $\mathrm{SO}_{2}{ }^{46}$ Direktivom

43 Direktiva 2005/33/EZ Europskog Parlamenta i Vijeća od 6. srpnja 2005. god. o izmjeni Direktive 1999/32/EZ (Directive 2005/33/EC of the European Parliament and of the Council of 6 July 2005 amending Directive 1999/32/EC), Official Journal of the European Union, L191, 22. 07. 2005., str. 59-69, dalje: Direktiva 2005/33/EZ.

44 Air Pollution: EU shipping strategy, str. 1. (dostupno na http://www.ecmeurope.net/2010/01/06/ air-pollution_eu_shipping-stra..., 9. 7.2015.).

45 Direktivom 2005/33/EZ mijenja se pojam brodskog goriva propisujući da se brodskim gorivom smatra svako tekuće gorivo dobiveno iz nafte namijenjeno za uporabu ili u uporabi na plovilu (čl. 2., st. 1., t. 3.). Direktiva 2005/33/EZ razlikuje brodsko dizelsko gorivo (svako brodsko gorivo čije su viskoznost ili gustoća u granicama za viskoznost ili gustoću - čl. 2., st. 1. pod 3.a) i brodsko plinsko ulje (svako brodsko gorivo koje ima viskoznost ili gustoću u granicama za viskoznost ili gustoću - čl. 2., st. 1. pod 3.b). Više o sadržajnoj razlici poimanja brodskih goriva prema rješenjima Direktive 1999/32/EZ vidjeti bilješku pod 40 .

46 U odnosu na područje Baltičkog mora - predmetna se odredba primjenjivala od 11. kolovoza 2006. god.; za Sjeverno more od 11. kolovoza 2007. god. 
Dr. sc. Željka Primorac: Ekološke i pravne posljedice uporabe brodskog pogonskog goriva sa... Zbornik radova Pravnog fakulteta u Splitu, god. 53, 2/2016., str. 553.-579.

2005/33/EZ normiran je najveći sadržaj sumpora u brodskim gorivima koja uporabljuju plovila za plovidbu unutrašnjim plovnim putovima na vezu u lukama u EU. Prema rješenjima čl. 4.b) predmetne direktive države članice EU bile su dužne od 1. siječnja 2010. god. ${ }^{47}$ poduzeti sve potrebne mjere kako bi osigurale da plovila za plovidbu unutrašnjim plovnim putovima i brodovi na vezu u lukama u EU ne uporabljuju brodska goriva čiji sadržaj sumpora prelazi 0,1\% masenog udjela. ${ }^{48}$

Osim normi kojima se prvi put pravno uređuju najveći sadržaj sumpora u gorivima za plovila koja se uporabljuju na područjima nadzora nad emisijama $\mathrm{SO}_{2}$ i koja rabe putnički brodovi na linijskoj plovidbi prema lukama u EU ili izvan njih (čl. 4.a) te najveći sadržaj sumpora u brodskim gorivima koja uporabljuju plovila za plovidbu unutrašnjim plovnim putovima i brodovi na vezu u lukama u EU (čl. 4.b), nove su i odredbe o odobravanju pokusa i uporaba novih tehnologija za smanjenje emisija (čl. 4.c) te odredbe o obvezama država članica EU uskladiti nacionalna zakonodavstva rješenjima Direktive 2005/33/EZ do 11. kolovoza 2006. god. ${ }^{49}$

\section{3. Direktiva 2012/33/EZ Europskog Parlamenta i Vijeća od 21. studenoga 2012. god. o izmjeni Direktive 1999/32/EZ u vezi sa sadržajem sumpora u brodskim gorivima}

Direktiva 2012/33/EZ Europskog parlamenta i Vijeća od 21. studenoga 2012. god. o izmjeni Direktive 1999/32/EZ u vezi sa sadržajem sumpora u brodskim gorivima ${ }^{50}$ donesena je kako bi se osiguralo usklađivanje s međunarodnim pravom (Prilogom VI. MARPOL konvencije) kao i prisilna provedba novih globalno utvrđenih standarda emisije $\mathrm{SO}_{2}$ u EU. Ovom direktivom dodatno se definiraju

47 Zbog tehničkih problema u prilagodbi navedenim rješenjima, brodovima je omogućeno prijelazno razdoblje do kraja kolovoza 2010. god. do kada su morali izvršiti nužne tehničke promjene i uporabiti brodsko gorivo sa smanjenim sadržajem sumpora (više vidi Implications on new regulation regarding sulphur content in ship's fuel on maritime transport sector within Baltic Sea Region, srpanj 2012., str. 6. (dostupno na http://www.transbaltic.eu/wp-content/uploads/2013/05/ImplicationsofnewRegulationFINAL.pdf. 20. 7. 2015.).

48 Zanimljivo je kako se navedena odredba, među ostalim, nije primjenjivala na brodove koji su prema objavljenom redu vožnje ostali na vezu manje od dva sata te na brodove koji su isključivali sve motore i služili se električnom energijom s obale dok su na vezu u lukama (čl. 4.b, st. a, d).

49 S obzirom na obvezujući karakter Direktive 2005/33/EZ, pojedine države članice EU nisu prilagodile nacionalna zakonodavstva rješenjima navedene direktive u roku pa je pred Europskim sudom pravde (The Court of Justice of the European Union, dalje: ECJ) pokrenut postupak protiv Austrije, Ujedinjenog Kraljevstva Velike Britanije i Sjeverne Irske (više vidjeti predmete C-107/08: Action brought on 7 March 2008 - Commission of the European Communities v Republic of Austria, OJ C 107, 26.4.2008., str.21.; C-394/09: Action brought on 6 October 2009 - Commission of the European Communities v United Kingdom of Great Britain, OJ C 282, 21. 11. 2009., str. 31-32).

50 Direktiva 2012/33/EZ Europskog Parlamenta i Vijeća od 21. studenoga 2012. god. o izmjeni Direktive 1999/32/EZ u vezi sa sadržajem sumpora u brodskim gorivima (Directive 2012/33/EC of the European Parliament and of the Council of 21 November 2012 amending Council Directive 1999/32/EC as regards the sulphur content of marine fuels), Official Journal of the European Union, L321, 27. 11. 2012., str. 1-13, dalje: Direktiva 2012/33/EZ. 
standardi za sadržaj sumpora u brodskim gorivima ${ }^{51}$ i propisuju strože vrijednosti u morskim područjima te u posebnim kontrolnim područjima emisija sumpora iz brodova. Najveći sadržaj sumpora u brodskim gorivima koja se koriste na području država članica EU ne smije prelaziti 3,5 \% mase. ${ }^{52}$ Prema odredbi čl. 4.a, st. 1., države članice su dužne poduzeti sve potrebne mjere kako bi osigurale da se u područjima njihovog teritorijalnog mora, isključivog gospodarskog pojasa i zona kontrole onečišćenja koja pripadaju kontrolnim područjima emisija $\mathrm{SO}_{2}$ ne koriste brodska goriva čiji sadržaj sumpora prelazi $1,00 \%$ do 31. prosinca 2014. god., $0,10 \%$ od 1 . siječnja 2015. god. ${ }^{53}$ Prema odredbi čl. 4.a, st. 1.a, države članice su dužne poduzeti sve potrebne mjere kako bi osigurale da se u područjima njihovog teritorijalnog mora, isključivih gospodarskih pojaseva i zona kontrole onečišćenja (dakle, u područjima koja ne pripadaju kontrolnim područjima emisije $\mathrm{SO}_{2}$ ) ne koriste brodska goriva čiji sadržaj sumpora prelazi 3,50\% od 18. lipnja 2014. odnosno $0,50 \%$ od 1 . siječnja 2020. Direktiva 2012/33/EZ mijenja odredbe u vezi $\mathrm{s}$ maksimalnim sadržajem sumpora u brodskim gorivima koje koriste brodovi na vezu u lukama EU. Odredbom čl. 4. b) Direktive 2012/33/EZ propisano je kako sadržaj sumpora u brodskim gorivima koje se koristi na vezu u lukama $\mathrm{EU}^{54}$ ne smije prelaziti $0,10 \%$ mase. $^{55}$

Obrazlažući kako bi bez provođenja mjera iz Direktive 2005/33/EZ emisije s brodova mogle biti više od emisije iz svih kopnenih izvora, ${ }^{56}$ rješenja iz ove direktive države članice EU bile su dužne implementirati do 18. lipnja 2014. god. i na taj način uskladiti europske pravne poretke glede onečišćenja zraka s brodova rješenjima Priloga VI. MARPOL konvencije.

51 Europski zakonodavac propisuje nove definicije brodskog dizelskog goriva (svako brodsko gorivo kako je utvrđeno za kategoriju goriva DMB iz tablice I. ISO 8217, osim upute na sadržaj sumpora) i brodskog plinskog ulja (svako brodsko gorivo kako je utvrđeno za kategoriju goriva DMX, DMA i DMZ iz tablice I ISO 8217, osim upute na sadržaj sumpora) - tako čl. 2., t. 3.a) i 3. b) Direktive 2012/33/EZ.

52 Čl. 3. a) Direktive 2012/33/EZ.

53 Više o radikalnim promjenama plovidbe u tim područjima prema rješenjima ove direktive vidi MATCZAK, M.: ",Redefining the Baltic Sea Maritime TransportGeography as a Result of a New Environmental Regulation for theSulphur Emission Control Areas', u: Marine Navigation and Safety of Sea Transportation, CRC Press, 2013., str. 249-253.

54 Novina se odnosi na činjenicu da europski zakonodavac više ne propisuje primjenu predmetnog rješenja u odnosu na plovila za plovidbu unutrašnjim plovnim putovima po uzoru na rješenja čl.4. b) Direktive 2005/33/EZ.

55 Značajno je ukazati kako je predmetni postotak temeljem Direktive 2012/33/EZ istovjetan rješenju iz Direktive 2005/33/EZ. Razlika je u tome što je europski zakonodavac u Direktivi 2005/33/EZ proširio primjenu i u odnosu na plovila koja plove unutrašnjim plovnim putovima te što je u odnosu na sadržaj sumpora u brodskom gorivu od 0,1\% propisao da se predmetna odredba primjenjivala od 1. siječnja 2010. god. (dakle, skoro 5. god. nakon donošenja Direktive 2005/33/EZ).

56 Vidjeti Preambula pod 4. Direktive 2012/33/EZ. 
Dr. sc. Željka Primorac: Ekološke i pravne posljedice uporabe brodskog pogonskog goriva sa... Zbornik radova Pravnog fakulteta u Splitu, god. 53, 2/2016., str. 553.-579.

\subsection{Provedbena Odluka Komisije (EU) 2015/253 od 16. veljače 2015. god. o utvrđivanju pravila uzorkovanja i izvješćivanja u skladu s Direktivom Vijeća 1999/32/EZ za sadržaj sumpora u brodskim gorivima}

Provedbena Odluka Komisije (EU) 2015/253 od 16. veljače 2015. god. o utvrđivanju pravila uzorkovanja i izvješćivanja u skladu s Direktivom Vijeća 1999/32/EZ za sadržaj sumpora u brodskim gorivima ${ }^{57}$ donesena je na temelju Direktive 1999/32/EZ čak 16 godina nakon njezina donošenja. Značaj ove Odluke očituje se pravnim normama kojima ova Odluka propisuje metode i učestalost uzorkovanja brodskih goriva koja se upotrebljavaju u brodovima.

Prema odredbi čl. 3., st. 1. Odluke (EU) 2015/253, države članice EU dužne su provoditi preglede brodskih dnevnika i dostavnica za gorivo na najmanje $10 \%$ ukupnog broja pojedinačnih brodova koji pristaju u EU državi članici godišnje. Od 1. siječnja 2016. god. sadržaj sumpora u brodskim gorivima koja se upotrebljavaju u brodovima provjerava se i uzorkovanjem ili analizom ili obama navedenim postupcima na najmanje sljedećem postotku pregledanih brodova (najmanje $10 \%$ ukupnog broja pojedinačnih brodova koji pristaju u predmetnoj državi članici godišnje - st. 1.): $40 \%$ za države članice koje u potpunosti graniče s područjima kontrole emisije $\mathrm{SO}_{2}, 30 \%$ za države članice koje dijelom graniče u područjima kontrole emisije $\mathrm{SO}_{2}, 20 \%$ za države članice koje ne graniče s područjima kontrole emisija $\mathrm{SO}_{2}$.

\subsection{Implementacija međunarodnih i europskih pravnih izvora u vezi sa smanjenjem onečišćenja zraka s brodova u hrvatski pravni poredak}

Brojni međunarodni ugovori čija je RH stranka uređuju pitanja zaštite zraka. ${ }^{58}$ Prema Protokolu o daljnjem smanjenju emisija $\mathrm{SO}_{2}$ iz 1994. god., $\mathrm{RH}$ se obvezala smanjiti emisiju $\mathrm{SO}_{2}$ za $17 \%$ do 2000. (u odnosu na 1990. god.). Te su procjene pokazivale da je uz dotadašnju regulativu bilo moguće postići smanjenje emisije do razine od 45.000 t/god. u 2010. god., što je smanjenje za $75 \%$ u odnosu na 1990. god. ${ }^{59} \mathrm{Na}$ temelju Protokola o suzbijanju zakiseljavanja, eutrofikacije i prizemnog ozona uz Konvenciju o dalekosežnom prekograničnom onečišćenju zraka iz 1979. god., RH je donijela Program postupnog smanjivanja emisija za određene onečišćujuće tvari u RH za razdoblje do kraja 2010. god., s projekcijama emisija

57 Provedbena Odluka Komisije (EU) 2015/253 od 16. veljače 2015. god. o utvrđivanju pravila uzorkovanja i izvješćivanja u skladu s Direktivom Vijeća 1999/32/EZ za sadržaj sumpora u brodskim gorivima (Commission Implementing Decision (EU) 2015/253 of 16 February 2015 laying down the rules concerning the sampling and reporting under Council Directive 1999/32/EC as regards the sulphur content of marine fuels), Official Journal of the European Union, L41, 17. 2. 2015., str. 55-59, dalje: Odluka (EU) 2015/253.

58 Više o zaštiti zraka u pravnom sustavu RH vidjeti BARBALIĆ, M.; NEĆAK, J.: „Zaštita zraka u pravnom sustavu Republike Hrvatske“, Zbornik radova Zaštita zraka '99, Śibenik, 1999., str. 107-115.

59 Više vidjeti NEĆAK, J.; PAPIŠTA, D.; JELAVIĆ, V.: „Ciljevi i mjere za djelotvornu zaštitu i poboljšanje kakvoće zraka u Republici Hrvatskoj“, Zbornik radova Zaštita zraka '99, Šibenik, 1999., str. 35 i 37. 
Dr. sc. Željka Primorac: Ekološke i pravne posljedice uporabe brodskog pogonskog goriva sa... Zbornik radova Pravnog fakulteta u Splitu, god. 53, 2/2016., str. 553.-579.

za razdoblje od 2010. do 2020. god. ${ }^{60}$ koji ima za cilj dugoročno smanjiti emisiju $\mathrm{SO}_{2}$ kako bi se trajno poboljšala kakvoća zraka na području RH. Također je važno ukazati kako je Vlada RH 2005. god. donijela Uredbu o potvrđivanju Protokola MARPOL konvencije iz 1997. god. ${ }^{61}$ čijim stupanjem na snagu (19. svibnja 2005. god.) u odnosu na RH on postaje dio pravnog poretka RH. S obzirom na temu ovog znanstvenog rada, iznimno je značajno kako je dio hrvatskog pravnog poretka, od navedenog datuma, postao i Prilog VI. MARPOL konvencije kojim se uređuje sprečavanje onečišćenja zraka s brodova. Prema Pravilu 14. Priloga VI. MARPOL konvencije, sadržaj sumpora svakog goriva koje se koristi na brodu nije smio prelaziti $4,5 \% \mathrm{~m} / \mathrm{m}$ odnosno $1,5 \% \mathrm{~m} / \mathrm{m}$ ako je riječ o području u kojem se nadzire ispuštanje $\mathrm{SO}_{2}$. Prema odredbi čl. 10. Pravilnika o zaštiti morskog okoliša u zaštićenom ekološko-ribolovnom pojasu Republike Hrvatske, ${ }^{62} \mathrm{u}$ navedenom području zabranjeno je onečišćenje zraka protivno odredbama Priloga VI. MARPOL konvencije. ${ }^{63}$

Ciljevi i prioriteti u zaštiti zraka, ozonskog sloja i ublažavanja klimatskih promjena izneseni su Planom zaštite zraka, ozonskog sloja i ublažavanja klimatskih promjena u Republici Hrvatskoj za razdoblje od 2013. - 2017. god. ${ }^{64}$ Tim mjerama osigurava se provedba hrvatskih propisa i pravne stečevine EU koja je prenesena u nacionalno zakonodavstvo - pa i Direktive 2012/33/EU. Prema poglavlju 10.2. Plana, ukupna emisija $\mathrm{SO}_{2}$ u 2011. god. bila je za $77 \%$ manja u odnosu na 1990. god. zbog poboljšane kakvoće tekućih naftnih derivata s obzirom na maseni sadržaj sumpora u njima, prestanak potrošnje domaćeg ugljena $s$ visokim sadržajem sumpora te istovremeno sve veće potrošnje prirodnog plina.

Zaštita zraka u RH uređena je Zakonom o zaštiti okoliša ${ }^{65}$ (kojim se među ostalim uređuju načela zaštite okoliša u okviru koncepta održivog razvoja - čl. 1.), Zakonom o zaštiti zraka ${ }^{66}$ te mnogobrojnim provedbenim propisima. Zakon o zaštiti zraka uređuje odgovornost za zaštitu zraka i ozonskog sloja te mjere za sprečavanje i smanjivanje onečišćavanja zraka (čl. 1.). Izmjenama i dopunama iz 2014. god. (na snazi od 24. travnja 2014. god.) propisano je kako su odredbe ovog zakona u skladu s odredbama direktive 1999/32/EZ te direktive 2012/33/EZ. Prema odredbi čl. 128. Zakona o zaštiti zraka, inspekcijski nadzor nad propisima kojima se donose granične vrijednosti i druge značajke vezano uz kvalitetu

60 Program postupnog smanjivanja emisija za određene onečišćujuće tvari u Republici Hrvatskoj za razdoblje do kraja 2010. god., s projekcijama emisija za razdoblje od 2010. do 2020. (NN, br. 152/2009).

61 Više vidjeti bilješku pod 21.

62 Pravilnik o zaštiti morskog okoliša u zaštićenom ekološko-ribolovnom pojasu Republike Hrvatske (NN, br. 47/2008).

${ }^{63}$ Detaljnije vidi ĆORIĆ, D.; DEBELJAK-RUKAVINA, S.: „Zaštita morskog okoliša u zaštićenomekološko ribolovnom pojasu Republike Hrvatske“, Zbornik Pravnog fakulteta u Rijeci, Rijeka, br. 2, 2008., str. 959-974.

64 Odluka o donošenju Plana zaštite zraka, ozonskog sloja i ublažavanja klimatskih promjena u Republici Hrvatskoj za razdoblje od 2013.-2017. godine (NN, br.139/2013).

65 Zakon o zaštiti okoliša (NN, br. 80/2013, 78/2015).

66 Zakon o zaštiti zraka (NN, br. 130/2011, 47/2014). 
brodskih goriva te način dokazivanja sukladnosti brodskih goriva koja se koriste provodi inspektor sigurnosti plovidbe ministarstva nadležnog za pomorstvo. ${ }^{67}$

Granične vrijednosti sastavnica i značajke kvalitete naftnih goriva u RH propisuje Uredba o kvaliteti tekućih naftnih goriva iz 2013. god., 2014. god. i 2015. god. koja predstavlja glavni instrument smanjenja emisije $\mathrm{SO}_{\mathrm{x}}$ u hrvatskom pravnom poretku. Uredba o kvaliteti tekućih naftnih goriva iz 2013. god. ${ }^{68}$ propisivala je kako granična vrijednost za sumpor kod brodskih goriva ${ }^{69}$ iznosi 1,5 $\% \mathrm{~m} / \mathrm{m}$ za brodsko dizelsko gorivo, $0,1 \%$ za brodsko plinsko ulje s tim da brodovi na vezu moraju koristiti brodska goriva s količinom sumpora od $0,1 \% \mathrm{~m} / \mathrm{m}$. Ovom su Uredbom u pravni poredak RH prenesena rješenja Direktive 1999/32/ EZ i Direktive 2005/33/EZ. Prema odredbi čl. 4., ova se Uredba primjenjivala na sve skupine tekućih naftnih goriva (tako i brodskog goriva) koja se koriste za izgaranje kod motora s unutarnjim izgaranjem plovila za plovidbu unutarnjim morskim vodama, teritorijalnim morem i morem nad kojim RH ostvaruje suverena prava.

Uredbom i izmjenama i dopunama Uredbe o kvaliteti tekućih naftnih goriva iz 2014. godine, ${ }^{70}$ u pravni poredak RH prenesena je Direktiva 2012/33/EU budući da je u međuvremenu navedena direktiva stupila na snagu. Ova Uredba u cijelosti mijenja odredbe čl. 14. i 15. Uredbe iz 2013. god., propisujući kako je granična vrijednost količine sumpora u brodskom gorivu broda koji plovi na unutarnjim morskim vodama i teritorijalnom moru te morskim područjima u kojima RH ostvaruje suverena prava najviše $3,5 \% \mathrm{~m} / \mathrm{m}$ od 18 . lipnja 2014. god., $0,5 \%$ od 1 . siječnja 2020. god. (čl. 14., st. 2.). Ova se rješenja primjenjuju na sva plovila koja plove pod svim zastavama, uključujući plovila čije je putovanje započelo izvan EU (čl. 14., st. 8.). Granična vrijednost količine sumpora u brodskom gorivu koje koristi vlasnik i/ili korisnik putničkog broda koji plovi na redovnim linijama u i iz luka na području RH i EU, unutarnjim morskim vodama i teritorijalnim morem nad kojim RH ostvaruje svoja suverena prava, koja ne pripadaju kontrolnim područjima onečišćenja od emisija $\mathrm{SO}_{x}$, najviše iznosi $1,5 \% \mathrm{~m} / \mathrm{m}$ do 1 . siječnja 2020. (čl. 14., st. 4.). Granična vrijednost količine sumpora u brodskom gorivu koje vlasnik i/ili korisnik broda na vezu u lukama RH koristi najviše iznosi 0,10 \% $\mathrm{m} / \mathrm{m}$ (čl. 14., st. 5.). ${ }^{71}$ Prema odredbi čl. 15., st.1.-2., svim plovilima koja plove pod

67 Inspektor sigurnosti plovidbe ministarstva nadležnog za pomorstvo provodi inspekcijski nadzor zaštite morskog okoliša. Detaljnije o provođenju inspekcijskog nadzora vidi u: Pravilnik o obavljanju inspekcijskog nadzora (NN, br. 39/2011, 112/2014, 33/2015). Prema odredbi čl. 3. predmetnog Pravilnika, inspekcijski nadzor obuhvaća i nadzor nad sadržajem sumpora u brodskom gorivu.

68 Uredba o kvaliteti tekućih naftnih goriva iz 2013. god. (NN, br. 113/2013).

69 Brodsko gorivo je svako tekuće naftno gorivo namijenjeno za uporabu ili koje je u uporabi na plovnim objektima (čl. 6., st.1., t. 4. Uredbe iz 2013. god.).

70 Uredba o izmjenama i dopunama Uredbe o kvaliteti tekućih naftnih goriva iz 2014. god. (NN, br. 76/2014).

71 Iznimno je omogućeno korištenje brodskog goriva s količinom sumpora višom od $0,10 \% \mathrm{~m} / \mathrm{m}$ brodovima u redovitim linijama koji se u luci zadržavaju manje od dva sata prema redu plovidbe i brodovima koji isključe sve motore za vrijeme boravka u luci - a opskrbljuju se električnom energijom s kopna (čl. 14., st. 6.). 
Dr. sc. Željka Primorac: Ekološke i pravne posljedice uporabe brodskog pogonskog goriva sa... Zbornik radova Pravnog fakulteta u Splitu, god. 53, 2/2016., str. 553.-579.

svim zastavama (uključujući i plovila čije je putovanje započelo izvan EU) bilo je dopušteno ploviti područjima teritorijalnog mora, isključivog gospodarskog pojasa i područja kontrole onečišćenja koja pripadaju kontrolnim područjima onečišćenja od emisija $\mathrm{SO}_{x}$ korištenjem brodskih goriva s količinom goriva do najviše $1,00 \% \mathrm{~m} / \mathrm{m}$ do 31. prosinca 2014. god., $0,10 \% \mathrm{~m} / \mathrm{m}$ od 1 . siječnja 2015 . god.

Uredbom o dopunama Uredbe o kvaliteti tekućih naftnih goriva iz 2015. god. ${ }^{72}$ hrvatsko zakonodavstvo u potpunosti se usklađuje s Direktivom 1999/32/EZ te Direktivom 2012/33/EU. Predmetnim rješenjima utvrđuje se nadležno tijelo za provedbu Provedbene Odluke Komisije (EU) 2015/253 od 16. veljače 2015. god. o utvrđivanju pravila uzorkovanja i izvješćivanja u skladu s Direktivom 1999/32/ EZ za sadržaj sumpora u brodskim gorivima. Kao nadležno tijelo određuje se Inspekcija sigurnosti plovidbe ministarstva nadležnog za pomorstvo (čl. 3.a).

\section{PRAVNA OSNOVA ODGOVORNOSTI I OSIGURANJA ZA ŠTETU NASTALU IZLIJEVANJEM BRODSKOG GORIVA SA SMANJENIM SADRŽAJEM SUMPORA U MORE}

Iako onečišćenje zraka izgaranjem sumpora iz brodskih pogonskih goriva ima negativan utjecaj na čistoću morskog okoliša, dugogodišnjom analizom posljedica onečišćenja morskog okoliša izlijevanjem pogonskog ulja u more uvidjelo se kako veliki trgovački brodovi u tankovima često imaju količinu pogonskog goriva koje premašuje količine nafte što je manji tankeri prevoze kao teret (a čiji sustav odgovornosti uređuje CLC konvencija). Procjenjuje se da je više od polovice zahtjeva za naknadu štete zbog onečišćenja mora uljem posljedica onečišćenja brodskim gorivom. ${ }^{73}$ Brodska pogonska goriva karakteristična su po izrazito visokoj viskoznosti i otpornosti na razgradnju, pa su stoga, ako se dogodi izlijevanje goriva s broda u more, teško uklonjiva i djelotvornost uobičajenih interventnih mjera koje se poduzimaju jest upitna. Naravno, te karakteristike utječu na poskupljenje troškova čišćenja, što nadalje rezultira vrlo visokim iznosima nastale štete.

U odnosu na štete od onečišćenja mora neophodno je spomenuti važeći međunarodni sustav odgovornosti za štetu zbog onečišćenja mora izlijevanjem pogonskog goriva prema Međunarodnoj konvenciji o građanskoj odgovornosti za štete izlijevanjem pogonskog ulja iz 2001. god. ${ }^{74}$ čijim se stupanjem na snagu

72 Uredba o dopunama Uredbe o kvaliteti tekućih naftnih goriva iz 2015. god. (NN, br. 56/2015).

73 BRAVAR, A.: Međunarodna konvencija o građanskoj odgovornosti za štetu zbog onečišćenja brodskim pogonskim gorivom, Bunker konvencija, Zgombić\&Partneri, Zagreb, 2007., str. 15.

74 Međunarodna konencija o građanskoj odgovornosti za štete izlijevanjem pogonskog ulja iz 2001. god. (International Convention on Civil Liability for Bunker Oil Pollution Damage, dalje: Bunker konvencija) donesena je u Londonu 23. ožujka 2001. god., a stupila je na snagu 21. studenog 2008. god. Do 14. srpnja 2015. god. 78 država je pristupilo Bunker konvenciji što obuhvaća 91,46\% svjetske tonaže (tako prema podacima sa stranice http://www.imo.org/About/Conventions/StatusOfConventions/ Documents/Summary\%20of\%20Status.xl, 22. srpnja 2015. god.). RH je pristupila navedenoj konvenciji 
Dr. sc. Željka Primorac: Ekološke i pravne posljedice uporabe brodskog pogonskog goriva sa... Zbornik radova Pravnog fakulteta u Splitu, god. 53, 2/2016., str. 553.-579.

zaokružuje odnosno dovršava sustav međunarodnopravne regulacije građanske odgovornosti za štete zbog onečišćenja mora uljem. ${ }^{75}$ Predmet reguliranja Bunker konvencije jest sprečavanje odnosno umanjenje posljedica onečišćenja mora pogonskim uljem koje prouzroče pomorski brodovi ili pomorska plovila bilo koje vrste (iz primjene su isključeni tankeri). Bitno je, dakle, da se radi o brodu koji nije tanker i koji za plovidbu koristi ,pogonska ulja“. ${ }^{76}$ Prema odredbi čl. 3., st. 1. Bunker konvencije, vlasnik broda ${ }^{77}$ je osoba odgovorna za onečišćenje mora izazvano izlijevanjem pogonskog ulja koje je bilo ukrcano na brod ili koje je proizašlo s broda. Njegova odgovornost je objektivna, ali ne postoji apsolutni kauzalitet. ${ }^{78}$ Prema odredbi čl. 7., st. 1 . Bunker konvencije, upisani vlasnik broda ${ }^{79}$ preko 1000 tona,${ }^{80}$ upisan u državi stranci ove konvencije, dužan je sklopiti ugovor o osiguranju ili nekom drugom financijskom jamstvu kao što su bankovna jamstva ili slična financijska jamstva, radi pokrivanja svoje odgovornosti za štetu zbog

2006. god., više vidjeti Zakon o potvrđivanju Međunarodne konvencije o građanskoj odovornosti za štetu onečišcenja pogonskim uljem iz 2001. god. (NN, MU br. 9/06). Detaljnije o Bunker konvenciji vidjeti ZHU, L.: „Can the Bunkers Convention Ensure Adequate Compensation for Pollution Victims?“”, Journal of Maritime Law and Commerce, Baltimore, vol. 40., no. 2., 2009., str. 203-219.

75 GRABOVAC, I.: „Međunarodni ugovori kao temelj ujednačavanja pomorskog prava - u povodu Zakona o izmjenama i dopunama Pomorskog zakonika“, 2008., Zbornik Pravnog fakulteta u Splitu, Split, god. 46., br. 2, 2009., str. 265.

76 Prema odredbi čl. 1., st. 1., t. 5. Bunker konvencije, pogonska ulja su sva ugljikovodikova mineralna ulja, uključujući i ulje za podmazivanje, koja se koriste ili se imaju namjeru koristiti za rad ili pogon broda, kao i ostaci tog ulja. Detaljnije vidjeti ZHU, L., op. cit., str. 22.

77 U smislu odredaba Bunker konvencije, vlasnikom broda smatraju se sljedeće osobe: vlasnik, uključujući i upisani vlasnik, zakupoprimatelj, upravitelj broda i brodar. Uočavamo da je riječ o širem krugu osoba koje se imaju smatrati vlasnikom broda i koje mogu odgovarati pa je značajno ukazati kako su se ovom rješenju protivili P\&I klubovi jer se tumačenjem odgovorne osobe za štetu zbog onečišćenja mora izlijevanjem pogonskog ulja $\mathrm{s}$ broda u smislu šireg kruga odgovornih osoba povećava i broj potencijalno tuženih osoba (detaljnije vidjeti GRABOVAC, I.: „Značenje Međunarodne konvencije o građanskoj odgovornosti u slučaju štete od onečišćenja brodskim gorivom“, 2001., Zbornik Pravnog fakulteta u Rijeci, Rijeka, supplement, br. 2., 2002., str. 221; ĆORIC, D.: Onečišćenje mora s brodova, Međunarodna i nacionalna pravna regulativa, Pravni fakultet Sveučilišta u Rijeci, 2009., str. 157).

78 Iz odredaba čl. 3., st. 3. i 4. Bunker konvencije, proizlazi mogućnost vlasnika broda osloboditi odgovornosti za prethodno navedenu štetu ako dokaže: a) da je šteta posljedica rata, neprijateljstava, građanskog rata, pobune ili iznimne, neizbježne i nesavladive prirodne pojave, ili b) da je šteta u cijelosti prouzročena radnjom ili propustom treće osobe učinjenima u namjeri da se prouzroči šteta, ili c) da je šteta u cijelosti prouzročena nemarom ili drugom štetnom radnjom bilo koje vlade ili drugoga tijela odgovornoga za održavanje svjetala ili drugih sredstava za pomoć plovidbi u obavljanju te funkcije, ili d) vlasnik može u cijelosti ili djelomično biti oslobođen odgovornosti prema oštećenoj osobi ako dokaže da je šteta zbog onečišćenja u cijelosti ili djelomično nastala bilo zbog radnje ili propusta oštećene osobe učinjenih bilo u namjeri da se prouzroči šteta, bilo zbog njezina nemara.

79 Iako za štetu od onečišćenja mora izlijevanjem pogonskog ulja odgovaraju vlasnik broda, uključujući i upisani vlasnik, zakupoprimatelj, upravitelj broda i brodar - obvezatnost osiguranja prema rješenjima Bunker konvencije tereti samo upisanog vlasnika broda (osobu ili osobe koje su upisane kao vlasnici broda, ili, u nedostatku upisa, osobu ili osobe koje posjeduju brod. Ako je brod vlasništvo države, a koristi ga društvo koje je u toj državi upisano kao brodar, izraz upisani vlasnik označava to društvo - čl. 1., st. 1., t. 4. Bunker konvencije). GRABOVAC, I.: „Međunarodna konvencija o građanskoj odgovornosti za štetu onečišćenja pogonskim uljem (2001.) i Republika Hrvatska“, Kapetanov glasnik, Udruga pomorskih kapetana u Splitu, Split, br. 14., 2007., str. 8: Osiguranje drugih osoba koje mogu odgovarati nije obvezno.

${ }^{80}$ Danas pomorski prijevoz obavlja više od 41.000 brodova s preko 1000 BT (više vidjeti dokument IMO, Legal Comittee, 94. sjednica, I:/LEG/94/11-2.doc, LEG 94/11/2 od 19. rujna 2008. god. - www. imo.org). 
Dr. sc. Željka Primorac: Ekološke i pravne posljedice uporabe brodskog pogonskog goriva sa... Zbornik radova Pravnog fakulteta u Splitu, god. 53, 2/2016., str. 553.-579.

onečišćenja, u visini svote koja odgovara granicama odgovornosti utvrđenima prema primjenjivom nacionalnom ili međunarodnom režimu ograničenja, ali da ni u kojem slučaju ne prijeđe svotu obračunatu u skladu s Konvencijom o ograničenju odgovornosti za pomorske tražbine iz 1976. god. ${ }^{81}$ kako je izmijenjena. Predmetna rješenja vrlo su značajna kada je riječ o šteti nastaloj izlijevanjem pogonskog goriva u more (neovisno o sadržaju sumpora) budući da će istu namiriti P\&I klub ako je brodar u odnosu na tu vrstu štete sklopio ugovor o pomorskom osiguranju tj. ako ima važeće osigurateljno pokriće u odnosu na tu vrstu štete prema pravilima P\&I klubova. No, osigurateljno pokriće P\&I kluba ne postoji u odnosu na troškove kazne koju je brodar platio zbog nekorištenja odgovarajućeg brodskog goriva. Naime, u području Sjevernog mora koje je proglašeno SECA područjem i u kojem je sadržaj sumpora u brodskom gorivu bio ograničen na 1 \% u 2012. god. - dva broda člana UK P\&I kluba bila su novčano kažnjena ${ }^{82}$ jer nisu upotrebljavala gorivo čiji je sadržaj sumpora bio najviše $1 \%{ }^{83}$ No, prema pravilu 19.4 UK P\&I kluba, iznimno ${ }^{84}$ se može pokriti u cijelosti ili u većem dijelu brodarevu odgovornost za štete koje su nastale brodaru kao članu tog P\&I kluba u odnosu na izvršeno plaćanje novčanih kazni zbog uporabe pogonskog goriva neodgovarajućeg sadržaja sumpora. Naime, svi članovi P\&I klubova moraju u potpunosti biti svjesni povećanih i postroženih mjera uporabe brodskog pogonskog goriva sa smanjenim sadržajem sumpora u cilju smanjenja emisija $\mathrm{SO}_{2}$ s brodova kao mehanizama kojih se moraju pridržavati te su dužni poduzeti sve mjere potrebne za usklađivanje sa zahtjevima Priloga VI. MARPOL konvencije.

81 Konvencija o ograničenju odgovornosti za pomorske tražbine iz 1976. god. (Convention on Limitation of Liability for Maritime Claims, dalje: LLMC 1976) stupila je na snagu 1. prosinca 1986. god. Detaljnije o njezinim rješenjima, kao i o izmjenama i dopunama LLMC 1976 vidjeti MARIN, J.: „Opće ograničenje odgovornosti brodovlasnika i doktrina forum non conveniens“, Poredbeno pomorsko pravo, Zagreb, br. 153., 1997., str. 37-51; MARIN, J.: „Treba li Republika Hrvatska pristupiti Protokolu iz 1996. o izmjeni Konvencije o ograničenju odgovornosti za pomorske tražbine, iz 1976?"“, Zbornik Pravnog fakulteta u Zagrebu, Zagreb, br. 1, 2003., str. 75-94; VASILJ, A.; BOŠNJAK, M.: „Sustavi općeg ograničenja odgovornosti u pomorskom pravu - potreba unifikacije pomorskog prava“, Zbornik Pravnog fakulteta u Splitu, Split, br. 3., 2011., str. 549-576.

82 Više vidjeti UK P\&I Club Risk Focus: Loss of Power (3/10/12), pravilo 19. - liability for pollution fines.

83 „Stricker air pollution regulations on the horizon, UK P\&I Club“, Legal Briefing, Stricker air pollution regulations on the horizon, lipanj 2014., str. 3. (dostupno na http://www.ukpandi.com/fileadmin/ uploads/uk-pi/Latest_Publications/LEGAL_BRIEFINGS/UKLegal_Emissions_web.pdf, 20. 7. 2015.).

84 Prema pravilima P\&I klubova, nadoknada isplaćenih novčanih kazni od strane brodara može biti pokrivena od strane P\&I kluba čiji je brodar član u sljedećim striktno propisanim slučajevima: ako se novčana kazna odnosi na kršenje imigracijskih zakona, povrede carinskih propisa, povrede vezano za neispravnu dokumentaciju o teretu te troškove nastale slučajnim onečišćenjem. S obzirom na izneseno, upravo bi se troškovi brodareve isplate novčane kazne nadležnim tijelima države na čijem području nije korišteno pogonsko gorivo propisanog sadržaja sumpora mogli tumačiti kao „slučajno onečišćenje“. Stoga novčane kazne vezane za kršenje odredbi Priloga VI. MARPOL konvencije mogu biti predmet osigurateljnog pokrića prema pravilima P\&I klubova, ali samo prema diskrecijskoj odluci direktora P\&I kluba (više vidjeti HARE, J.: „Fines \& P\&I Cover“, The P\&I Column (dostupno na www.skuld.com/ upload/News and Publications/Publications/PIColumns/PI_07.pdf, 14. 7. 2015.) 


\section{PROBLEMATIKA UPORABE BRODSKOG GORIVA SA SMANJENIM SADRŽAJEM SUMPORA DE LEGE FERENDA}

Postupanje prema Prilogu VI. MARPOL konvencije odgovornost je brodara ${ }^{85}$ koji je kao pomorski poduzetnik dužan poduzeti sve mjere kako bi omogućio izvršenje ugovora o prijevozu stvari morem. ${ }^{86} \mathrm{U}$ prvom redu misli se na sljedeće: brod čiji motori nisu u mogućnosti koristiti brodsko gorivo sa smanjenim sadržajem sumpora u posebnim područjima zapravo nije osposobljen za globalnu trgovinsku plovidbu te slijedom toga brod nije u mogućnosti slijediti zapovijedi naručitelja koji za vrijeme trajanja predmetnog ugovora u komercijalnom smislu raspolaže brodom ${ }^{87}$ i može zahtijevati da brod plovi unutar posebnih područja sa smanjenim sadržajem sumpora. Neupitno je da brod mora ploviti u skladu s međunarodnim propisima pa troškove preinake broda, omogućavanja plovidbe brodu i u SECA područjima snosi brodar budući da će u slučaju neispunjenja međunarodnih zahtjeva brodar biti novčano kažnjen. ${ }^{88}$

Prelazak na brodsko gorivo nižeg sadržaja sumpora utjecat će na povećanje brodarovih troškova pa je značajno ukazati kako je Śvedska još 1998. god. uvela smanjene pristojbe u svojim lukama i plovnim putovima za trajekte koji su koristili gorivo s postotkom sumpora manjim od $0,5 \%$ i teretne brodove koji su koristili gorivo s postotkom sumpora manjim od $1 \%$, utječući tako da su i prije stupanja na snagu Priloga VI. MARPOL konvencije te implementacije europske pravne stečevine u pogledu smanjenja emisije SOx s brodova (smanjenjem sadržaja sumpora u brodskom gorivu) - čak 80 \% ulaza u švedske luke činili takvi brodovi. ${ }^{89}$

Pravno normiranje smanjenja emisija $\mathrm{SO}_{2}$ uvođenjem nižih granica maksimalnog sadržaja sumpora u brodskom pogonskom gorivu (na međunarodnoj i europskoj razini) rezultiralo je nastankom određenih problema u praksi uslijed primjene brodskog goriva niže razine sadržaja sumpora. Radi se prvenstveno o sljedećima: većim troškovima nabave skupljeg (čišćeg) goriva, ${ }^{90}$ većim

${ }^{85}$ Ako je riječ o ugovoru o prijevozu putnika i prtljage morem - predmetna obveza tereti prijevoznika.

86 PAVIĆ, D.: Pomorsko imovinsko pravo, Književni krug, Split, 2006., str. 102: U brodarskim ugovorima na vrijeme (time charter, ugovor je o prijevozu stvari morem kojim se brodar obvezuje da će u ugovorenom vremenu i ugovorenim brodom obavljati za naručitelja prijevoze, a naručitelj se obvezuje da će za to vrijeme plaćati ugovorenu vozarinu i troškove pogona. On je dužan na svoj trošak opskrbljivati brod pogonskim gorivom, mazivom i vodom potrebnom za pogonske strojeve i druge strojne uređaje. Detaljnije vidjeti Sulphur content in ships bunker fuel in 2015, A study on the impacts of the new IMO regulations on transportation costs, Ministry of Transport and Communications Finland, 2009., str. 30. (dostupno na https://www.lvm.fi/docs/en/339549 DLFE-8042.pdf, 20. 7. 2015.).

87 PAVIĆ, D.: Pomorsko imovinsko pravo, op. cit., str. 102.

88 Više vidjeti kod CHOURDAKI, D.: New low sulphur emissions in ECAs (dostupno na www. swedishclub.com/.../Triton_1_2015_The\%20S..., 13. 7. 2015.).

89 Tako prema LENĀA, K., op. cit., str. 24.

90 Razlika u cijeni između goriva s malim postotkom sumpora (1\% ili manje) i goriva s velikim postotkom sumpora $(3,5 \%)$ u prosjeku iznosi oko 19 \$ po toni goriva (Ibid, str. 23). Očekuje se da će cijene teškog dizelskog goriva rasti $20 \%$ u 2015. god te će to značiti $50 \%$ veću cijenu u odnosu na cijenu goriva koju su brodari plaćali prije novih propisa. Više o smanjenju sadržaja sumpora u gorivu te 
troškovima investiranja $u$ nove tehnologije i brodsku opremu na postojećim brodovima, ${ }^{91}$ problemima glede opskrbe ${ }^{92}$ i skladištenja tog goriva na brodovima, nekompatibilnosti između različitih vrsta brodskih goriva sa smanjenim sadržajem sumpora, problemima vezanima za zakašnjenja koja nastaju zbog nužnosti prelaženja broda s pogonskog goriva većeg sadržaja sumpora na manje (i obratno) zbog različitog normiranja maksimalnog sadržaja sumpora u brodskom gorivu ovisno je li riječ o plovidbi unutar ili izvan SECA područja. Manje značajni nisu ni problemi vezani za tehničke poteškoće u radu dizelskih motora zbog promjene goriva poglavito kada je brod u pogonu (u plovidbi), ali i za štete koje mogu nastati pogonskim strojevima stalnom izmjenom goriva različite strukture, kompatibilnosti i značajnih promjena u temperaturi izgaranja goriva. Stoga kao posljedice promjene brodskog goriva (čiji sadržaj sumpora ne prelazi $1 \%$ na goriva čiji sadržaj sumpora ne prelazi $0,1 \%$ ) mogu nastati i kvarovi brodskog motornog sustava zbog gubitka struje na brodu, ${ }^{93}$ oštećenja električnih uređaja zbog zastoja u opskrbi brodskih motora pogonskim gorivom itd. U Kaliforniji su se do srpnja 2014. god. dogodila 93 gubitka pogona broda (nestanka struje) te je u odnosu na 15 slučajeva dokazano da je riječ o nestanku struje zbog promjene goriva tj. prelaska na brodsko gorivo 0,1 postotnog sadržaja sumpora. ${ }^{94}$ Prema rezulatima analize P\&I klubova, 7 \% odštetnih zahtjeva u odnosu na odštetne zahtjeve trećih osoba zbog oštećenja imovine ${ }^{95}$ odnosi se na oštećenja glavnih pogonskih motora i nestanka struje uslijed problema s promjenom goriva (,fuel problems"). Naime, budući da brod bez struje može prouzročiti velika oštećenja dokovima, mostovima, brodovima i morskom okolišu, veliku opasnost predstavlja svakodnevno povećanje broja takvih događaja posebice u trenucima kada brod obavlja manevre. ${ }^{96}$ Oštećenje brodskih motora zbog gubitka struje na brodu (izazvanog promjenama brodskog goriva različite razine sumporovog sadržaja) nije osigurljiv rizik prema pravilima P\&I klubova. No, može biti osigurljiv rizik

neophodnom povećanju kvalitete goriva kao mjerama koje poskupljuju proizvodnju goriva i povisuju cijenu goriva vidjeti ŠANTIĆ, L.; VILKE, S.; GRUBIŠIĆ, N.: „Čimbenici štetnog djelovanja cruisingturizma na brodski okoliš“", Naše more, br. 5-6, 2011., str. 230.

${ }_{91}$ Novi brodovi će imati manje troškova jer će odmah biti izgrađeni u skladu sa zahtjevima međunarodnih standarda u odnosu na troškove preinake postojećih brodova.

92 Zbog povećane potražnje, opskrba odnosno dostupnost brodskog goriva s maksimalnim sadržajem sumpora od 0,1 \% može biti upitna (gorivo sa smanjenim sadržajem sumpora manje je dostupno i skuplje zbog većih troškova proizvodnje). Stoga brodari ne smiju pretpostaviti kako će predmetno gorivo biti osigurano za njih prilikom njihova dolaska u luke. U odnosu na putničke brodove dostupnost tog goriva utjecat će i na odluke o destinaciji putovanja. Naime, nedostatak takvog goriva u pojedinim (većim) lukama može utjecati i na promjene ruta putovanja što dodatno može povećati troškove kružnih putovanja koje će snositi putnici.

93 Iznenadni gubitak struje na brodu moguć je kao posljedica primjene goriva različite viskoznosti.

94 Statistički podaci pokazuju da je vrlo vjerojatno kako će se incidenti vezani za nestanak pogona broda u Engleskom kanalu događati svaka tri dana (više vidjeti http://www.swedishclub.com/main. php? $\mathrm{mcid}=109 \& \mathrm{pid}=1 . ., 13.7$. 2015.).

95 Riječ je o odštetnim zahtjevima čiji iznosi prekoračuju nekoliko milijuna američkih dolara.

96 Više vidjeti Risk Focus Bulletin, UK P\&I Club, Low Sulphur Power Loss Warning (dostupno na http://maritimeaccident.org/2012/10/low-sulphur-power-loss-warnin..., 13. 7. 2015.) 
ako je riječ o osiguranju trupa broda ili strojeva broda. ${ }^{97}$ Temeljem odredbe čl. 726., st. 1. Pomorskog zakonika, ${ }^{98}$ osiguranje broda obuhvaća trup broda, njegove strojeve, uređaje i opremu, redovite zalihe goriva, maziva i ostalog brodskog materijala te zalihe hrane i pića potrebne za posadu broda. ${ }^{99}$

$\mathrm{S}$ obzirom na iznesene poteškoće u primjeni brodskog goriva smanjenog sadržaja sumpora ( $1 \%, 0,1 \%$ ovisno o područjima plovidbe), u praksi se sve više zagovara uporaba alternativnog goriva (biodizela - pogonskog brodskog goriva koje gotovo da i nema sumpora; biogoriva i drugih obnovljivih goriva za prijevoz ${ }^{100}$ ili usvajanje tehnologije za pročišćivanje plina. Kao jedna od mogućnosti preporuča se i upotreba ukapljenog prirodnog plina (LNG) koji kao pročišćeni prirodni plin, najčišće fosilno gorivo (neobnovljivi izvor energije) ne sadrži sumpor te se stoga preporuča za plovila u cilju postizanja propisanog smanjenja sadržaja sumpora u brodskim gorivima u područjima kontrole emisije $\mathrm{SO}_{2}$ koje se odnosi na polovicu brodova koji plove u europskom pomorskom prometu na kratkim udaljenostima. ${ }^{101}$ No, vrlo je skupo i iznimno teško izvršiti preinaku ${ }^{102}$ postojećih brodova u odnosu na omogućavanje brodovima korištenje LNG-a kao pogonskog goriva posebice u odnosu na činjenicu da predmetna preinaka neupitno znači i prenamjenu dijela broda i smanjenje kapaciteta broda u odnosu na prijevoz tereta.

$\mathrm{S}$ obzirom na to da su emisije $\mathrm{SO}_{2}$ s brodova još uvijek jedno od područja koje je najmanje regulirano propisima, ${ }^{103}$ negativni učinci globalnog obilježja pomorske industrije zahtijevaju da se u interesu kvalitetnog funcioniranja te industrije, ali i sustavnog pristupa problematici onečišćenja zraka ispušnim plinovima s brodova, ustroje sveobuhvatna međunarodnopravna rješenja, provodeći dugogodišnje mjere za sprečavanje i smanjivanje onečišćenja zraka.

97 Više o osigurateljnom pokriću temeljem sklopljenog ugovora o osiguranju broda vidjeti ZHU, L., op. cit., str. 57-58.

98 Pomorski zakonik (NN, br. 181/2004, 76/2007, 146/2008, 61/2011, 56/2013, 26/2015, dalje: PZ).

99 Detaljnije vidi PAVIĆ, D.: Ugovorno pravo osiguranja, Tectus, Zagreb, 2009., str. 556-557.

100 Detaljnije vidi Direktivu 2003/30/EZ o promicanju upotrebe biogoriva i drugih obnovljivih goriva za potrebe prijevoza (Directive 2003/30/EC of the European Parliament and of the Council of 8 May 2003 on the promotion of the use of biofuels or other renewable fuels for transport, Official Journal of the European Union, L123, 17. 05. 2003, str. 42-46). Više vidjeti Zakon o biogorivima za prijevoz (NN, br. 65/2009, 145/2010, 26/2011, 144/2012, 14/2014).

101 Detaljnije o problemu onečišćenja zraka i upotrebi LNG-a na brodovima vidjeti AMIŽIĆ JELOVČIĆ, P.; PRIMORAC, Ž.; ŠKURLA, I.: „Energetska perspektiva Republike Hrvatske s posebnim osvrtom na zaštitu Jadranskog mora“, Zbornik Pravnog fakulteta u Splitu, Split, br. 4, 2013., str. 840-841.

102 Promjena pogona ili propulzivnog sistema na brodu spada u zahvate koji su dosta česti kod starijih brodova, ali i kod novijih brodova na kojima brodar želi jedan pogon zamijeniti drugim, obično modernijim i ekonomičnijim (tako prema HLAČA, V.: Hrvatsko pomorsko pravo, izabrani radovi, Pravni fakultet Sveučilišta u Rijeci, Rijeka, 2001., str. 348).

103 ZANNE, M.; TWRDY, E., op. cit., str. 101. 


\section{ZAKLJUČAK}

Aktualnost problematike sprečavanja i smanjenja emisije $\mathrm{SO}_{2}$ dodatno naglašavaju svakodnevne informacije o negativnim posljedicama klimatskih promjena, emisijama stakleničkih plinova, oštećenja ozona i globalnog zagrijavanja. Iz navedenih razloga na globalnoj razini potrebno je utjecati na smanjenje emisija $\mathrm{SO}_{\mathrm{x}}$ sustavnim pristupom zaštiti zraka. Odvijanje pomorskog prometa ima nesumnjivo globalni predznak kao važna gospodarska djelatnost budući da zbog jeftinog i efikasnog prijevoza stimulira međunarodnu trgovinu. Ipak, odvijanje pomorskog prijevoza ima i značajne negativne učinke s obzirom na činjenicu da je moderan svijet u potpunosti ovisan o prometu koji koristi fosilna goriva (naftu) koja je ekološki neprihvatljiva budući da njezinim sagorijevanjem dolazi do ispuštanja štetnih tvari u okoliš, pa tako i $\mathrm{SO}_{2}$. Iako je sumpor u malim količinama prisutan u nafti, više od $90 \%$ sumpora iz goriva emitira se u obliku $\mathrm{SO}_{2}$. Stoga nije beznačajan podatak da jedan cruiser dnevno proizvodi količinu smoga jednaku onoj koju uzrokuje 350.000 automobila ${ }^{104}$ što ne začuđuje ako uzmemo u obzir da brodovi koriste brodsko pogonsko gorivo lošije kvalitete $\mathrm{u}$ odnosu na dizelsko gorivo koje koriste cestovna motorna vozila.

Onečišćenje zraka kao rezultat emisije izgaranja brodskog pogonskog goriva predmet je međunarodne kontrole prema Prilogu VI. MARPOL konvencije, posebice u odnosu na tehničke zahtjeve vezane za sadržaj sumpora u pogonskom brodskom gorivu kao mjerama koje imaju za cilj spriječiti ili smanjiti razinu onečišćenja zraka emisijama $\mathrm{SO}_{2}$. Kronološkom analizom promjena predmetnih rješenja autorica ukazuje kako od 1. siječnja 2015. god. sadržaj sumpora u brodskom gorivu u posebnim područjima nadzora nad emisijama sumpora (SECA područja) ne smije prelaziti $0,1 \%$ odnosno u ostalim područjima do 1 . siječnja 2020. god. - sadržaj sumpora ne smije prelaziti $0,50 \%$. Usporedbom prenošenja predmetnih rješenja u sekundarno zakonodavstvo EU (Direktiva 1999/32/EZ, Direktiva 2005/33/EZ, Direktiva 2012/33/EZ, Provedbena odluka Komisije br. 2015/253) te njihovom kvalitetnom implementacijom u hrvatski pravni sustav autorica zaključuje kako uspostavljanje boljih emisijskih standarda na globalnoj razini povlači za sobom sljedeće učinke: povećanje troškova pomorskog prijevoza zbog ispunjavanja navedenih tehničkih mjera, provođenje strožih kontrola onečišćenja zraka $s$ brodova te značajnije povećanje troškova za brodare koji zbog manje dostupnosti takvog goriva (i njegove skuplje cijene) mogu očekivati veće financijsko opterećenje budući da troškovi goriva čine čak $60 \%$ operativnih troškova broda. Također, neupitni su i troškovi koji će nastati zbog nužne preinake i osuvremenivanja globalne flote zbog ispunjavanja ekoloških zahtjeva. Problemi zbog opskrbe navedenim gorivom, ali i problemi koje nekompatibilno brodsko gorivo različite strukture može uzrokovati samom radu brodskih motora s obzirom na različita područja plovidbe i različita ograničenja sadržaja sumpora u brodskom gorivu mogu uzrokovati poteškoće u radu brodskih motornih sustava zbog kvarova i gubitka struje. Ukazujući na rješenja P\&I klubova glede

104 ŠANTIĆ, L.; VILKE, S.; GRUBIŠIĆ, N., op. cit., str. 231. 
osigurateljnog (ne)pokrića u odnosu na predmetne štete, dodatno je naglašena važnost pronalaženja rješenja problema primjene brodskog goriva sa smanjenim sadržajem sumpora, uvažavajući javne interese zaštite okoliša i privatne interese svih sudionika plovidbenog pothvata. S obzirom na činjenicu da se $90 \%$ svjetske trgovine obavlja morskim putem, globalno obilježje pomorskog brodarstva zahtijeva i međunarodno pravno uređenje. Iako je očito kako su IMO pravila o sadržaju sumpora u brodskom gorivu još uvijek preniska (budući da najveći brodovi mogu svaki pojedinačno emitirati oko 5000 tona sumpora godišnje što odgovara onečišćenju koje godišnje prouzroči 50 milijuna automobila), ${ }^{105}$ primjena brodskog goriva sa smanjenim sadržajem sumpora svakako pridonosi smanjenju emisija $\mathrm{SO}_{2}$ u prometu, boljem radnom učinku brodova i manjim troškovima održavanja. Kako više od 100. 000 brodova plovi morem i kako svjetska pomorska flota ispušta u atmosferu značajne količine $\mathrm{SO}_{2}$ predlaže se uvođenje boljih emisijskih standarda na globalnoj razini. Budući da je riječ o neobnovljivim izvorima energije, jedan od prijedloga odnosi se na upotrebu ukapljenog prirodnog plina ${ }^{106}$ ili biogoriva kao pogodnog alternativnog goriva za plovila kojim se može postići propisano smanjenje sadržaja sumpora.

\section{Popis literature}

\section{Članci i knjige}

1. ABEL, D. A.; McCONNELL, R. L: Environmental Oceanography: Topics and Analysis, Jones \& Bartlett Publishers, 2009.

2. AMIŽIĆ JELOVČIĆ, P.; PRIMORAC, Ž.; ŠKURLA, I.: „Energetska perspektiva Republike Hrvatske s posebnim osvrtom na zaštitu Jadranskog mora“, Zbornik Pravnog fakulteta u Splitu, Split, br. 4., 2013.

3. BARBALIĆ, M.; NEĆAK, J.: „Zaštita zraka u pravnom sustavu Republike Hrvatske“, Zbornik radova Zaštita zraka '99, Šibenik, 1999.

4. BRAVAR, A.: Međunarodna konvencija o građanskoj odgovornosti za štetu zbog onečišćenja brodskim pogonskim gorivom, Bunker konvencija, Zgombić\&Partneri, Zagreb, 2007.

5. COLLS, J.; TIWARY, A.: Air pollution, Measurement, Modelling and Mitigation, CRC Press, 2009.

6. ĆORIĆ, D.: Onečišćenje mora s brodova, Međunarodna i nacionalna pravna regulativa, Pravni fakultet Sveučilišta u Rijeci, 2009.

7. ĆORIĆ, D.; DEBELJAK-RUKAVINA, S.: „Zaštita morskog okoliša u zaštićenom ekološko-ribolovnom pojasu Republike Hrvatske“, Zbornik Pravnog fakulteta u Rijeci, Rijeka, br. 2., 2008.

105 ZANNE, M.; TWRDY, E., op. cit., str. 104.

106 Više o prirodnom plinu kao alternativnom gorivu vidjeti PAWELSKI, J.: „Natural Gas as Alternative Fuel for Vessels Sailing in European Waters", u: Marine Navigation and Safety of Sea Transportation, CRC Press, 2013., str. 103-107; Implications on new regulation regarding sulphur content in ship's fuel on maritime transport sector within Baltic Sea Region, op. cit., str. 11-13. 
Dr. sc. Željka Primorac: Ekološke i pravne posljedice uporabe brodskog pogonskog goriva sa... Zbornik radova Pravnog fakulteta u Splitu, god. 53, 2/2016., str. 553.-579.

8. DAVENPORT, J.; DAVENPORT, J. L.: The Ecology of Transportation: Managing Mobility for the Environment, Springer, Nizozemska, 2006.

9. FRANK, V.: The European Community and MarineEnvironmental Protection in the International Law of the Sea, BRILL, 2007.

10. GILlESPIE, A.: Climate Change, Ozone Depletion and Air Pollution, BRILL, 2006.

11. GRABOVAC, I.: „Značenje Međunarodne konvencije o građanskoj odgovornosti u slučaju štete od onečišćenja brodskim gorivom, 2001.“, Zbornik Pravnog fakulteta u Rijeci, Rijeka, supplement, br. 2, 2002.

12. GRABOVAC, I.: „Međunarodni ugovori kao temelj ujednačavanja pomorskog prava - u povodu Zakona o izmjenama i dopunama Pomorskog zakonika, 2008.“, Zbornik Pravnog fakulteta u Splitu, Split, god. 46., br. 2, 2009.

13. GRABOVAC, I.: „Međunarodna konvencija o građanskoj odgovornosti za štetu onečišćenja pogonskim uljem (2001.) i Republika Hrvatska“, Kapetanov glasnik, Udruga pomorskih kapetana u Splitu, Split, br. 14, 2007.

14. HLAČA, V.: Hrvatsko pomorsko pravo, izabrani radovi, Pravni fakultet Sveučilišta u Rijeci, Rijeka, 2001.

15. JUGOVIĆ, A.; ŽANIĆ MIKULIČIĆ, J.; MAGLIĆ, L.: „Impact of external costs on the implementation of Motorways of the Sea system“, Pomorstvo, Pomorski fakultet u Rijeci, br.1, 2014.

16. KACHEL, M. J.: Particularly Sensitive Sea Areas: The IMO's Role in Protecting Vulnerable Marine Areas, Springer Science \& Business Media, 2008.

17. KHEE-JIN TAN, A.: Vessel-Source Marine Pollution: The Law and Politics of International Regulation, Cambridge University Press, 2005.

18. LEGIŠA, I.: „Što nam donosi smanjenje sadržaja sumpora u gorivima“, Goriva $i$ maziva, Hrvatsko društvo za goriva i maziva, Zagreb, br. 4, 2002.

19. LENAC, K.: „Metode smanjivanja emisije štetnih tvari s brodova“, Pomorstvo, Rijeka, br. 1, 2005.

20. LUTTENBERGER, A.: Pomorsko upravno pravo, Sveučilište u Rijeci, Pomorski fakultet, Rijeka, 2008.

21. MARIN, J.: „Opće ograničenje odgovornosti brodovlasnika i doktrina forum non conveniens“, Poredbeno pomorsko pravo, Zagreb, br. 153, 1997.

22. MARIN, J.: „Treba li Republika Hrvatska pristupiti Protokolu iz 1996. o izmjeni Konvencije o ograničenju odgovornosti za pomorske tražbine, iz 1976?“", Zbornik Pravnog fakulteta u Zagrebu, Zagreb, br. 1, 2003.

23. MATCZAK, M.: „Redefining the Baltic Sea Maritime TransportGeography as a Result of a New Environmental Regulation for theSulphur Emission Control Areas", u: Marine Navigation and Safety of Sea Transportation, CRC Press, 2013.

24. MILOŠEVIĆ PUJO, N.; JURJEVIĆ, N.: „Onečišćenje mora iz zraka emisijom ispušnih plinova“, Naše more, br. 5-6, 2004.

25. MUKHERJEE, P. K.; BROWNRIGG, M.: Farthing on International Shipping, Springer, 2013. 
Dr. sc. Željka Primorac: Ekološke i pravne posljedice uporabe brodskog pogonskog goriva sa... Zbornik radova Pravnog fakulteta u Splitu, god. 53, 2/2016., str. 553.-579.

26. NEĆAK, J.; PAPIŠTA, D.; JELAVIĆ, V.: „Ciljevi i mjere za djelotvornu zaštitu i poboljšanje kakvoće zraka u Republici Hrvatskoj“, Zbornik radova Zaštita zraka '99, Šibenik, 1999.

27. PAVIĆ, D.: Pomorsko imovinsko pravo, Književni krug, Split, 2006.

28. PAVIĆ, D.: Ugovorno pravo osiguranja, Tectus, Zagreb, 2009.

29. PAWELSKI, J.: „Natural Gas as Alternative Fuel for Vessels Sailing in European Waters", u: Marine Navigation and Safety of Sea Transportation, CRC Press, 2013.

30. POSAVEC, Z.: „Zahtjevi za aditivima nove generacije za dizelska goriva“, Goriva i maziva, Hrvatsko društvo za goriva i maziva, Zagreb, br. 2, 2005.

31. POSAVEC, Z.: „Tko se boji sumpora još?“, Goriva i maziva, Hrvatsko društvo za goriva i maziva, Zagreb, br. 4, 2005.

32. REDGWELL, C.: „The Application of International Law“, u: International Law, OUP Oxford, 2010.

33. SAIFUL, K. MD.: Prevention of Pollution of the Marine Environment from Vessels: The Potential and Limits of the International Maritime Organisation, Springer, 2014.

34. SERŠIĆ, M.: Međunarodno-pravna zaštita morskog okoliša, Pravni fakultet Sveučilišta u Zagrebu, Zagreb, 2003.

35. SIMPSON, D.; JERZY BARTNICKI, J.; JALKANEN, J. K.; HANSSON, H. C.; HERTEL, O.; LANGER, J.; PRYOR, S. C.: „Environmental Impacts Atmospheric Chemistry“, u: Second Assessment of Climate Change for the Baltic Sea Basin, Springer, 2015.

36. SONG, D. W.; PANAYIDES, P. M.: Maritime Logistics: Contemporary Issues, Emerald Group Publishers, 2012.

37. STANKOVIĆ, P.: Pomorske havarije, Školska knjiga, Zagreb, 1995.

38. ŠANTIĆ, L.; VILKE, S.; GRUBIŠIĆ, N.: „Čimbenici štetnog djelovanja cruising-turizma na brodski okoliš“, Naše more, br. 5-6, 2011.

39. VASILJ, A.; BOŠNJAK, M.: „Sustavi općeg ograničenja odgovornosti u pomorskom pravu - potreba unifikacije pomorskog prava“, Zbornik Pravnog fakulteta $u$ Splitu, Split, br. 3, 2011.

40. WILCOX, E. R.: Digest of United States Practicein International Law, Oxford University Press, 2012.

41. ZANNE, M.; TWRDY, E.: „Air Pollution from Maritime Transport - the Problem of Today, the Challenge of Tommorow", Pomorstvo, br. 1, 2011.

42. ZHU, L.: „Can the Bunkers Convention Ensure Adequate Compensation for Pollution Victims?", Journal of Maritime Law and Commerce, Baltimore, vol. 40, no. 2, 2009.

\section{Pravni propisi}

1. Direktiva Vijeća 1999/32/EZ od 26. travnja 1999. god. o smanjenju sadržaja sumpora $\mathrm{u}$ određenim tekućim gorivima, Official Journal of the European Communities, L121, 26. 04. 1999.

2. Direktiva 2005/33/EZ Europskog Parlamenta i Vijeća od 6. srpnja 2005. god. 
Dr. sc. Željka Primorac: Ekološke i pravne posljedice uporabe brodskog pogonskog goriva sa... Zbornik radova Pravnog fakulteta u Splitu, god. 53, 2/2016., str. 553.-579.

o izmjeni Direktive 1999/32/EZ, Official Journal of the European Union, L191, 22. 07. 2005.

3. Direktiva 2012/33/EZ Europskog Parlamenta i Vijeća od 21. studenoga 2012. god. o izmjeni Direktive 1999/32/EZ u vezi sa sadržajem sumpora u brodskim gorivima, Official Journal of the European Union, L321, 27. 11. 2012.

4. Direktiva 2003/30/EZ o promicanju upotrebe biogoriva i drugih obnovljivih goriva za potrebe prijevoza, Official Journal of the European Union, L123, 17. 05. 2003.

5. Konvencija o prekograničnom onečišćenju zraka na velikim udaljenostima iz 1979. god.

6. Konvencija o ograničenju odgovornosti za pomorske tražbine iz 1976. god.

7. MARPOL konvencija 1973/1978.

8. Međunarodna konvencija o građanskoj odgovornosti za štete izlijevanjem pogonskog ulja iz 2001. god.

9. Odluka o objavljivanju mnogostranih međunarodnih ugovora kojih je Republika Hrvatska stranka na temelju notifikacija o sukcesiji (NN, MU, br. 12/1993).

10. Pomorski zakonik (NN, br. 181/2004, 76/2007, 146/2008, 61/2011, 56/2013, 26/2015).

11. Pravilnik o zaštiti morskog okoliša u zaštićenom ekološko-ribolovnom pojasu Republike Hrvatske (NN, br. 47/2008).

12. Pravilnik o obavljanju inspekcijskog nadzora (NN, br. 39/2011, 112/2014, 33/2015).

13. Protokol o smanjenju emisija sumpora ili njihovog prekograničnog strujanja za najmanje $30 \%$ iz 1985. god.

14. Protokol o daljnjem smanjenju emisije $\mathrm{SO}_{2}$ iz 1994. god.

15. Protokol o suzbijanju zakiseljavanja, eutrofikacije i prizemnog ozona iz 1999. god.

16. Protokol o izmjenama i dopunama MARPOL konvencije iz 1997. god.

17. Provedbena Odluka Komisije (EU) 2015/253 od 16. veljače 2015. god. o utvrđivanju pravila uzorkovanja i izvješćivanja u skladu s Direktivom Vijeća 1999/32/EZ za sadržaj sumpora u brodskim gorivima, Official Journal of the European Union, L41, 17. 02. 2015.

18. Uredba o objavi Protokola iz 1997. god. kojim se mijenja i dopunjuje Međunarodna konvencija o sprečavanju onečišćenja s brodova iz 1973. (NN, MU, br. 4/05).

19. Uredba o kvaliteti tekućih naftnih goriva iz 2013. god. (NN, br. 113/2013).

20. Uredba o izmjenama i dopunama Uredbe o kvaliteti tekućih naftnih goriva iz 2014. god. (NN, br. 76/2014).

21. Uredba o dopunama Uredbe o kvaliteti tekućih naftnih goriva iz 2015. god. (NN, br. 56/2015).

22. Zakon o potvrđivanju Konvencije o dalekosežnom prekograničnom onečišćenju zraka iz 1979. god. (NN, MU, br. 17/1998).

23. Zakon o potvrđivanju Protokola o suzbijanju zakiseljavanja, eutrofikacije i prizemnog ozona uz Konvenciju o dalekosežnom prekograničnom onečišćenju zraka (NN, MU, br.4/2008). 
Dr. sc. Željka Primorac: Ekološke i pravne posljedice uporabe brodskog pogonskog goriva sa... Zbornik radova Pravnog fakulteta u Splitu, god. 53, 2/2016., str. 553.-579.

24. Zakon o zaštiti okoliša (NN, br. 80/2013, 78/2015).

25. Zakon o zaštiti zraka (NN, br. 130/2011, 47/2014).

26. Zakon o potvrđivanju Međunarodne konvencije o građanskoj odovornosti za štetu onečišćenja pogonskim uljem iz 2001. god. (NN, MU br. 9/06).

\section{Sudska praksa}

1. Case C-107/08: Action brought on 7 March 2008 - Commission of the European Communities v Republic of Austria, OJ C 107, 26. 4. 2008.

2. Case C-394/09: Action brought on 6 October 2009 - Commission of the European Communities v United Kingdom of Great Britain, OJ C 282, 21. 11. 2009.

\section{Ostala dokumentacija}

1. Air Pollution: EU shipping strategy (http://www.ecmeurope.net/2010/01/06/airpollution_eu_shipping-stra...).

2. Bijela knjiga, Plan za jedinstveni europski prometni prostor - Put prema konkurentnom prometnom sustavu unutar kojeg se učinkovito gospodari resursima. Bruxelles, COM(2011) 144 final, 28. 3. 2011.

3. CHOURDAKI, D.: New low sulphur emissions in ECAs (www.swedishclub. com/.../Triton_1_2015_The\%20S...).

4. Designation of Emission Control Area to Reduce Emissions from Ships in the U.S. Caribbean, Office of Transportation and Air Quality EPA-420-F-11-024, 2011.

5. EU encourages stringent measures, UK P\&I Club, Legal Briefing, Stricker air pollution regulations on the horizon, lipanj 2014. (http://www.ukpandi.com/fileadmin/ uploads/uk-pi/Latest_Publications/LEGAL_BRIEFINGS/UKLegal_Emissions_web. pdf).

6. HARE, J.: Fines \& P\&I Cover, The P\&I Column (www.skuld.com/upload/News and Publications/Publications/PIColumns/PI_07.pdf).

7. IMO, Legal Comittee, 94. sjednica, I:/LEG/94/11-2.doc, LEG 94/11/2 od 19. rujna 2008. god. - www.imo.org.

8. Implications on new regulation regarding sulphur content in ship's fuel on maritime transport sector within Baltic Sea Region, srpanj 2012. (http://www.transbaltic. eu/wp-content/uploads/2013/05/ImplicationsofnewRegulationFINAL.pdf).

9. Increasing emissions, u: Air Pollution from ships, 2004. ( http://www. transportenvironment.org/sites/te/files/media/2004-11_joint_ngo_air_pollution_from_ ships.pdf).

10. LEWIS, G.: How 16 cars create as much pollution as all the cars in the world, 2009. (http://www.dailymail.co.uk/sciencetech/article-1229857/How-16-shi...).

11. Marpol Annex VI sets sulphur test (http://dnv.no/din_bransje/maritime/ publikasjoner/publications...).

12. MITROPOULOS, E. E.: Poruka u povodu svjetskog dana pomorstva (http:// www.mppi.hr/default.aspx?id=4098). 
Dr. sc. Željka Primorac: Ekološke i pravne posljedice uporabe brodskog pogonskog goriva sa... Zbornik radova Pravnog fakulteta u Splitu, god. 53, 2/2016., str. 553.-579.

13. Odluka o donošenju Plana zaštite zraka, ozonskog sloja i ublažavanja klimatskih promjena u Republici Hrvatskoj za razdoblje od 2013.-2017. godine (NN, br. 139/2013).

14. PRELEC, Z.: Inženjerstvo zaštite okoliša (www.riteh.uniri.hr/zav-katd-sluz/ zvd_teh-term_energ).

15. Prevention of air pollution from ships, UK P\&I Club, Legal Briefing, Stricker air pollution regulations on the horizon, lipanj 2014. (http://www.ukpandi.com/fileadmin/ uploads/uk-pi/Latest_Publications/LEGAL_BRIEFINGS/UKLegal_Emissions_web. pdf).

16. Program postupnog smanjivanja emisija za određene onečišćujuće tvari u Republici Hrvatskoj za razdoblje do kraja 2010. god., s projekcijama emisija za razdoblje od 2010. do 2020. (NN, br. 152/2009).

17. Rezolucija MEPC.176(58), 10. listopada 2008. (http://www.imo.org/blast/ blastDataHelper.asp?data_id=23760\&filename=176\%2858\%29.pdf).

18. Risk Focus Bulletin, UK P\&I Club, Low Sulphur Power Loss Warning (http:// maritimeaccident.org/2012/10/low-sulphur-power-loss-warnin...).

19. Special Areas under MARPOL (http://www.imo.org/en/OurWork/Environment/ SpecialAreasUnde...).

20. Stationary sources vs ships, u: Air Pollution from ships (http://www. transportenvironment.org/sites/te/files/media/2004-11_joint_ngo_air_pollution_from_ ships.pdf).

21. Stricker air pollution regulations on the horizon, UK P\&I Club, Legal Briefing, Stricker air pollution regulations on the horizon, lipanj 2014. (http://www.ukpandi. com/fileadmin/uploads/uk-pi/Latest_Publications/LEGAL_BRIEFINGS/UKLegal_Emissions_web.pdf).

22. Sulphur content in ships bunker fuel in 2015, A study on the impacts of the new IMO regulations on transportation costs, Ministry of Transport and Communications Finland, 2009. (https://www.lvm.fi/docs/en/339549_DLFE-8042.pdf).

23. Third IMO GHG Study 2014 (http://www.imo.org/Our/Work/Environment/ PollutionPrevention/Air).

24. Truck versus ship emissions, u: Air Pollution from ships (http://www. transportenvironment.org/sites/te/files/media/2004-11_joint_ngo_air_pollution_from_ ships.pdf).

\section{Internetski izvori}

1. http://www.imo.org/About/Conventions/StatusOfConventions/Documents/ Summary $\% 20$ of $\% 20$ Status.xls

2. http://www.swedishclub.com/main.php?mcid=109\&pid=1...

3. www.unece.org/fileadmin/DAM/env/lrtap/full text/1985.Sulphur.e.pdf

4. Www.imo.org 
Dr. sc. Željka Primorac: Ekološke i pravne posljedice uporabe brodskog pogonskog goriva sa... Zbornik radova Pravnog fakulteta u Splitu, god. 53, 2/2016., str. 553.-579.

\section{ENVIRONMENTAL AND LEGAL CONSEQUENCES OF THE USE OF BUNKER MARINE FUELS WITH REDUCED SULPHUR CONTENT}

The author considers the ecological and legal consequences of the use of marine fuels with reduced sulfur content in the reduction of $\mathrm{SO}_{2}$ emissions from ships. Analyzing the efficaciously of the international and european legal instruments for the implementation of air protection, the author compares the solutions of Annex VI. MARPOL Convention with secondary EU legislation (Directive 1999/32/EC, Directive 2005/33/EC, Directive 2012/33/EC and Commission Implementing Decision (EU) 2015/253) and the success of their transfer to the croatian legal system. Noting on the institutional framework of the international and european legislation author outlines valid international system of civil liability for bunker oil pollution damage from ships (regardless of the sulfur content of the fuel) according to solutions of the International Convention on Civil Liability for Bunker Oil Pollution Damage, 2001.

With comprehensive analysis problems of practical application of marine fuel with reduced sulfur content it was considered the effect of harmonization with european environmental requirements to increase the cost of sea transport. The author emphasizes the unsustainability of transport system due to many years of $90 \%$ strength dependence of the maritime transport on oil, i.e. a non-renewable energy source and points to the use of alternative fuels.

Key words: marine fuels, reduced sulphur content 